\title{
ASPECTOS DE LA CULTURA MATERIAL DE LA NOBLEZA EN EL NORTE DEL EBRO DURANTE EL ANTIGUO RÉGIMEN
}

\author{
Pablo Orduna Portús \\ Red Cultural-Kultursarea-Cultural Network
}

\begin{abstract}
RESUMEN: En el presente estudio nos planteamos la cuestión de si cabe hablar de una cultura propia del grupo nobiliario. Está claro que por 'cultura nobiliar' debemos entender una pluralidad de valores, creencias y pautas de comportamiento de un espectro determinado de la población. Con tal fin, abarcaremos desde el estudio de su arquitectura habitacional al de su vestimenta. En definitiva, intentaremos lograr una historia cultural de dos hechos artísticos y sociales de la nobleza navarra a lo largo de la Modernidad.
\end{abstract}

Palabras clave: Nobleza, palacio, vestimenta, cultura material.

ABSTRACT: The present study will examine the existence of a real nobiliar culture in Navarre. This kind of culture was a plurality of values, beliefs and behavior patterns of a certain spectrum of the population, the elite. In this study we will analyze the architecture and their clothing. We will try to achieve this cultural history; two artistic and social events throughout Modernity. On the one hand the evolution of the palaces and secondly the social purpose of their costumes.

Keywords: Nobility, palace, clothing, material culture. 
LABURPENA: Ikerketa honetan berezko nobleen estamentu gorenetako kultura material baten izatea aztertuko dugu. Argia dago, 'noblezia-kultura' bezala herriaren espektro zehatz baten balio, uste, iritzi eta jokabidezko jarraibideen aniztasun batek ulertu behar dugun. Hori dela eta, bere bizi-arkitektura eta janzkeraren ikerketa gainbegiratuko dugu. Azken batean, Modernitatean Nafarroako nobleziaren bi arte eta gizarte-gertaeren historia kultural bat lortu saiatuko dugu.

Gako-hitzak: Noblezia, jauregia, janzkera, kultura materiala.

El estudio histórico de la vida cotidiana de un grupo social requiere un acercamiento a diferentes aspectos de su cultura material. En el caso de la nobleza navarra, parece conveniente dos de ellos que nos permiten comprobar si sus miembros mantenían o no unas pautas de comportamiento y vida social diferenciadas respecto al resto de habitantes del Reino. Con objeto de rastrear las posibles particularidades de este estilo de vida y sus coincidencias con el de otros estratos poblacionales, se analizarán en el siguiente artículo la casa del noble y sus formas de vestir. Nuestro principal objetivo no será sino examinar si los miembros del estamento privilegiado abandonaron plenamente su vida rural anterior y si, como otras noblezas hispanas y europeas, optaron por una vida urbana y palaciega frente a sus antiguas residencias en aislados castillos. A su vez, nos resulta de especial interés el estudio de las manifestaciones estéticas de estas nuevas residencias. Creemos posible descifrar a través de ellas un nuevo código pictográfico que nos acercará a la nueva filosofía de vida y valores nobiliares de la Modernidad. Así mismo, nos ofrecerá una visión de la forma en que estos caballeros mostraron a su entorno vecinal su concepción de grupo privilegiado y elite comunitaria. Estos aspectos se verán reflejados especialmente en las modas, normas y costumbres de uso del traje que imperaron en Navarra a lo largo del Antiguo Régimen. Por otra parte, entre las múltiples ocupaciones cotidianas que merecen nuestra atención se encuentran las del vestir y el comer. Intentaremos ver si en ellas, además de una necesidad vital, se inscribía el deseo de distinción, notoriedad y exclusividad propio de la cultura honorífica de la sociedad estamental.

\section{Castillos, casas fuertes y palacios: la imagen del poder}

\subsection{La arquitectura señorial navarra durante el Antiguo Régimen}

En Navarra la desaparición de los castillos defensivos tras las demoliciones sistemáticas ordenadas entre 1512 y 1521, dio paso a la edificación de nuevos 
palacios, o jauregiak' de carácter residencial ${ }^{2}$. En 1893, Boissonnade aseguraba que los citados derribos afectaron por igual a las poblaciones adscritas al bando agramontés como a las que lo estaban con el beamontés ${ }^{3}$. Todavía en 1644, el cronista Eguía y Beaumont continuaba añorando la hermosa fábrica del castillo de Estella que había sido mandado derruir por el virrey Gonzaga setenta años antes. El navarro resaltaba del edificio ya desaparecido "las vistosas galerías de que lo compusieron los reyes, donde solían tener su real palacio". Sin embargo, a pesar del derrumbe de las fortificaciones existieron comarcas navarras rebosantes de edificaciones palaciegas y casas-fuertes o de labor con aire guerrero. Resulta así, que el abad de Barásoain, don Francisco de Elorza y Rada en su Nobiliario del valle de la Valdorba de 1714 apuntaba que a principios del siglo $\mathrm{XVIII} \mathrm{esta} \mathrm{comarca} \mathrm{estaba} \mathrm{llena} \mathrm{de} \mathrm{torres} \mathrm{y} \mathrm{edificios} \mathrm{nobiliarios} \mathrm{en} \mathrm{estado} \mathrm{vario}$ de conservación. Unos arruinados, otros medianamente conservados y algunos restaurados ${ }^{4}$.

Tras el desmochamiento de las torres ordenada por Carlos I y Cisneros, los edificios que quedaron en pie sufrieron importantes remodelaciones que acabaron trasformándolos en palacios residenciales a lo largo de la Modernidad ${ }^{5}$. Esto ocurriría por ejemplo en la regata del Bidasoa, repleta de casas nobiliarias, que

1. Vocablo vasco cuya traducción en castellano es la de 'palacio'. Se repite frecuentemente para aludir a diferentes casas señoriales navarras (Baztán, Donamaría, Valle de Goñi, Lumbier) al igual que el de jauregizar-palacio viejo. En la Baja Navarra las casas de la nobleza, ligadas a la propiedad y el edificio señorial con derecho de asilo, se llamaban también 'jauregia' -casa del señor-; 'dorrea' -torre- o 'salha' -del gascón 'salle'-. ALTADILL, J., Castillos medievales de Navarra. Zarautz, 1935, II, p. 121.

2. A comienzos del siglo XV, numerosos castillos navarros se hallaban en estado de ruina $y$ sin guarnición en su interior. En algunos de los casos esta situación venía desde la primera invasión castellana de 1378. MARTINENA, J. J., Navarra, castillos y palacios. Pamplona, 1980, p. 21. En los últimos años de la independencia del Reino, sólo los castillos de Pamplona, Tudela, Estella, Viana, Sangüesa, Lumbier y San Juan de Pie de Puerto estaban en condiciones de resistir los envites de la nueva maquinaria bélica y la artillería. Villalba, encargado de llevar a cabo las demoliciones, escribió lo siguiente al cardenal Cisneros tras ejecutar su orden: "Navarra está tan baja de fantasía después que vuestra señoría reverendísima mandó derrocar los muros, que no hay hombre que alce la cabeza". Citado por SAGREDO, I., Navarra. Castillos que defendieron el Reino. Pamplona, 2006, p. 15.

3. BOISSONNADE, P., Histoire de la réunion de la Navarre a la Castille: Essai sur les relations des princes de Foix-Albret avec la France et l'Espagne (1479-1521). Genève, 1975, III, p. 413.

4. ELORZA Y RADA, F. de, Nobiliario del Valle de la Valdorba. Madrid, 1958.

5. ECHEVERRÍA GOÑII, P. L., "Casas señoriales y palacios del siglo XVI". GARCÍA GAINZA, Ma. C., (coord.). El Arte en Navarra. Pamplona, 1994, p. 281; Cámara Muñoz, A., Arquitectura y sociedad en el Siglo de Oro. Idea, traza y edificio. Madrid, 1990, p. 90. 
en pleno siglo XVIII conoció un fenómeno de renovación de la arquitectura doméstica gracias a las grandes fortunas amasadas por algunos de sus paisanos. Los Borda, familia bidasotarra, pueden ser un buen ejemplo, cuando en 1702 contrataban a los canteros Gaztambide "naturales de la provincia de Labort" para "hacer y fabricar su casa" sita en Maya y que se encontraba en malas condiciones ${ }^{6}$. Se observa cómo los antiguos linajes banderizos fueron reconstruyendo a lo largo de la Edad Moderna sus antiguas casas-torre dándoles evidentes aires palaciegos. En la Ribera el castillo de Marcilla, sede de los marqueses de Falces, fue enriquecido con un mirador renacentista. En Traibuenas la fortaleza medieval levantada en el siglo XIV se transformó en el Palacio de Miranda en el Quinientos. Para ello se recreció la mole arquitectónica con dos cuerpos de ladrillo y un ático así como con la adicción de cuatro torreones romboidales en sus ángulos confiriéndole una inusual simetría al edificio de planta central

En cualquier caso, la arquitectura señorial instalada en el Viejo Reino se encontraba inserta en un amplio territorio que englobaba las montañas de Burgos y Cantabria, la Alta Rioja, Álava, Vizcaya y Guipúzcoa. Tampoco se puede dejar de señalar que dentro de este marco geográfico existían matices locales, referidos a técnicas constructivas y a las funcionalidades de estos edificios, que revelaban peculiaridades incluso tipológicas. De esta manera, mientras que la zona cantábrica del Reino se relacionaba más con las casas-torre guipuzcoanas, Tierra Estella lo hacía con la Rioja y la Llanada Alavesa y la ribera tudelana con las tierras aragonesas y riojanas del Ebro. Aún con todo, los factores de cohesión seguían siendo más fuertes que los contrarios ${ }^{8}$. Esta relativa riqueza tipológica era otra de las características más relevantes de la arquitectura señorial en Navarra. Tal variedad venía determinada por factores como la funcionalidad de cada uno de los edificios, las condiciones geográficas del lugar donde estaba emplazado, el clima, los materiales constructivos utilizados y el periodo artístico predominante en el conjunto. A todo este tipo de construcciones se unían las casas hidalgas rurales, de gran sobriedad en cuanto a sus elementos ornamentales. Podemos poner como ejemplo significativo la casa Jarola en Elbetea. En ellas la labra heráldica sirvió para poder diferenciarlas frente a las correspondientes al pueblo llano ${ }^{9}$. Aunque en época renacentista se levantaron algunas

6. Archivo de Protocolos Notariales de Pamplona [APNP], notario Juan de Echeverz, 1702, 30-x, contrato de obras. El lugar de Gambo hace referencia a la villa de Cambo le Bain en Laborda (País Vasco Francés).

7. CARO BAROJA, J., Etnografía histórica de Navarra. Pamplona, 1995, II, pp. 86-94

8. BARRIO LOZA, J. A., "La arquitectura señorial en Euskadi". RAMALLO, A., (coord.). Arquitectura señorial en el norte de España. Oviedo, 1993, pp. 163-164.

9. TARIFA, Ma. J., "La imagen del poder de la nobleza navarra del siglo XVI a través de la promoción de obras de arte". VI Congreso de Historia de Navarra. Navarra: Memoria e imagen, vol. II (2006), pp. 508-522. 
de ellas con puerta adintelada, lo más común desde mitad del siglo XVI fue el arco de medio punto. Las casas se elevaban en tres alturas con ventanas adinteladas y balcones que lucían buenas obras de forja.

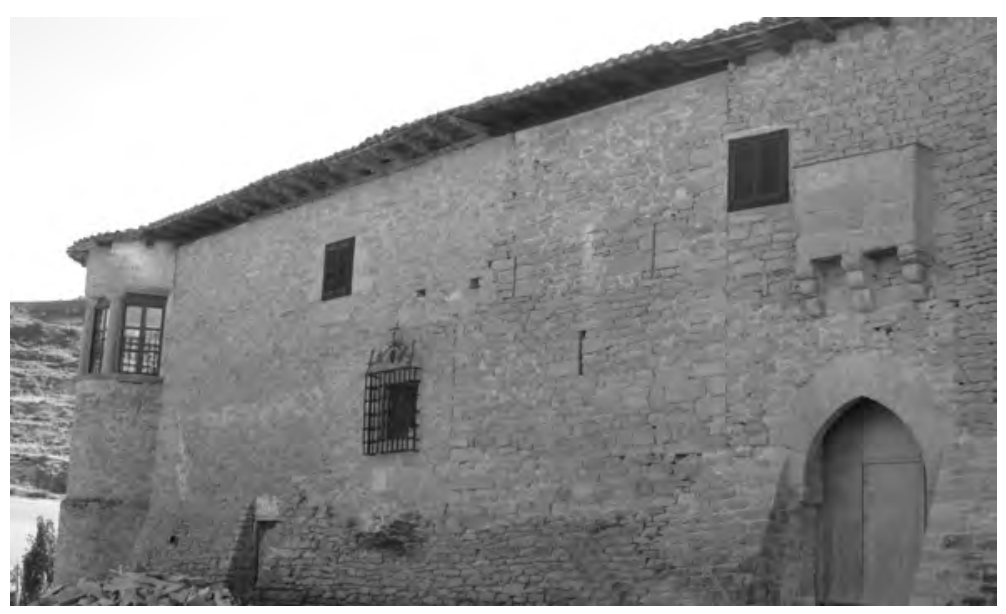

Figura 1: Casa palacio de Echarren de Guirguillano ${ }^{10}$.

Con arreglo a un criterio geográfico, el palacio era una construcción más característica de la Montaña y la Zona Media de Navarra. Esto no quiere decir que no existieran ejemplos riberos sino que los que hay tienen algunas características diferenciadoras. Estos últimos pueden relacionarse más con construcciones semejantes de Aragón y Castilla. Por el contrario, atendiendo a un criterio estilístico, al final de la Edad Media se implantaron rasgos constructivos renacentistas. Se aprecia por ejemplo un aire manierista (cercano a las obras de Peruzzi, Sangallo o Vignola) en la fachada de la Casa Motza de Andosilla. A su vez, lo 'italiano' es apreciable en el Palacio de Andéraz en Abárzuza a través de su noble cuerpo, dos pisos y dos alas laterales ${ }^{11}$. Este estilo clasicista perduraría durante todo el siglo XVI y parte del XVII hasta la eclosión del Barroco en las casas señoriales del Seiscientos y Setecientos. Podemos entonces señalar ya como muestra propia del Barroco palaciego navarro la casa Arizkunenea de Elizondo, hogar de descanso del marqués de Iturbieta o la casa Sanz Orrio de Roncal, excelente muestra de la arquitectura palacial de la segunda mitad del siglo XVIII. Sin embargo, al margen de las reglas generales de estas corrientes artísticas, en

10. Fuente: Foto de Pablo Orduna Portús. 2009.

11. ECHEVERRÍA GOÑII, P. L., "Casas señoriales y palacios...", p. 282 
Navarra hay que señalar la existencia de ciertos prototipos estructurales que Ilegaron a superar los cánones tipológicos. Se encuentran de esta manera cuatro tipos básicos de construcciones palacianas: la casa-torre cuadrangular de la montaña, las de dos torres, las de cuatro y por último la casona con ventanales y balconadas de tres o cuatro alturas y tejado a cuatro aguas. En Navarra, los escudos desde el siglo XVII pasaron a ocupar un lugar elevado y preeminente sobre el dintel del balcón principal o en el paño del piso principal. En el Barroco las puertas se decoran con más profusión y las armas del linaje bajan al dintel, que desde 1750 se verá recargado decorativamente por un estilo rococó. En las casas más sencillas el único elemento diferenciador que poseían respecto a sus convecinos era la presencia de un blasón familiar.

Las características generales del palacio barroco navarro se plasman en inmuebles que mostraban un bloque imponente y majestuoso. Además de un aspecto ornamental daban la sensación de solidez y aspecto macizo. Estas características no eran propias sólo del edificio barroco y se venían arrastrando desde la Baja Edad Media. Así por ejemplo, el palacio de Cábrega, en la Berrueza puede ser considerado una versión "a lo moderno" de la arquitectura tradicional ya existente ${ }^{12}$. Mientras que el palacio de la Montaña tiene buenas muestras en el valle de Baztán con tipos de casonas de campo, en Tierra Estella y la Ribera esto cambia. Allí lo urbano, al igual que en Pamplona, es un rasgo predominante. No obstante, en tanto que en Tierra Estella se mezcla la piedra y el ladrillo, en la ribera tudelana el palacio representó una variante más ligada a las grandes casas señoriales aragonesas vinculadas con el estilo mudéjar ${ }^{13}$. Un ejemplo de ello podría ser el palacio de la familia Magallón, conocido por el de los marqueses de San Adrián, en Tudela.

Desde el Renacimiento, por otra parte, los programas plásticos de sus fachadas brindaban a sus estructuras un carácter parlante. En el siglo XVI tales murales ponían en evidencia la cultura humanística de sus propietarios. Estos programas pictóricos estaban basados en leyendas mitológicas, alcanzando un protagonismo especial el tema de Hércules, paradigma del héroe virtuoso clá$\operatorname{sico}^{14}$. Podemos apreciar obras de este tipo en las casas urbanas de Tudela y

12. RIVAS CARMONA, J., "Una propuesta de tipología del palacio barroco en Navarra" Príncipe de Viana, Primer Congreso General de Historia de Navarra, anejo 11 (1988), pp. 415427.

13. No debemos olvidar el gran contingente arabizado que pobló los márgenes del río Ebro incluso aún en el siglo XVI y que popularizó el uso del ladrillo como material por excelencia en una construcción de tipo mudéjar. CHUECA GOITIA, F., "Arquitectura del siglo XVI". Ars Hispaniae: Historia Universal del Arte Hispánico, XI (1953), pp. 283-310.

14. A comienzos de la Edad Moderna Hércules era considerado en la mentalidad nobiliar como un modelo de virtudes y valores: "Ser Hércules hijo de Júpiter y Almera no es otra cosa sino la bondad y fortaleza y excelencia de las fuerzas del ánima y del cuerpo, que alanza y desbarata la batalla de todos los vicios del ánima, como se da a entender por su nombres, por- 
Estella. Un ejemplo a destacar dentro de la decoración palacial barroca navarra son las pinturas del palacio del Marqués de Huarte, sito en el casco urbano de Tudela. Ésta estaba compuesta por guirnaldas en los marcos de los vanos e imágenes de personajes clásicos en los pisos. Así, en la planta noble del edificio estaban pintadas unas parejas de faunos y cariátides a modo de soportes que apean en plintos y ménsulas a la vez que sostenían el entablamento partido. En éste último aparecen en sus extremos dos figuras ecuestres con el caballo en corbeta y en el centro una gran concha rodeada de motivos que enlazaban con el siguiente cuerpo del edificio. En el piso superior se presentaban unos baquetones quebrados en formas mixtilíneas encuadrando sus vanos, al tiempo que sustentaban telas, floreros y volutas con remates en conchas $^{15}$. Ya durante el Barroco los señores navarros muchas veces se conformaron con un austero despliegue de grandiosidad aunque en otras ocasiones pretendieron realzar su calidad social añadiendo a los muros cierto ornato decorativo mediante el uso de los materiales constructivos.

Simón García en 1681 en un manuscrito sobre la arquitectura expresaba claramente la necesidad e importancia en las casas de los grandes señores de las "salas espaciosas y adornadas". Las consideraba como los espacios más representativos de estas viviendas, reuniendo en este grupo a las lonjas, salones, patios y escaleras. Y es que, si existió un lugar señalado para la representación pública de la cultura nobiliaria desde finales del siglo XVII y durante todo el siglo XVIII, éste fue sin duda la escalera palaciega. Se constituyó en el verdadero eje de los edificios, ya que el resto de dependencias y la vida cotidiana se distribuían en torno a ellas reemplazando la función organizadora del patio renacentista. En algunos casos presentaba una gran complejidad constructiva y teatralidad, con una cubierta abovedada profusamente decorada y vanos por los que entraba la luz de forma intencionada a modo de linterna ${ }^{16}$. Sin embargo, su escenografía no se limitaba a aspectos de la caja y su cubierta sino que intentaba llegar a la plenitud en el juego de los tramos de peldaños. En algunos casos dos o tres perpendiculares entre sí rodeaban el perímetro de la caja, aunque en

que primero fue Ilamado Alcides, de alce en griego, que significa fuerza. Luego [fue Ilamado] Hércules, que quiere decir fortaleza y prudencia; y la razón que está en el hombre, y constancia, sin la divina bondad, y sin buen sujeto de ánimo, no acontece". PÉREZ DE MOYA, J., Philosofía secreta donde debaxo de historias fabulosas se contiene mucha doctrina provechosa a todos estudios. Con el origen de los ídolos o dioses de la gentilidad. Es materia muy necessaria para entender poetas y historiadores. Madrid, 1995, p. 443.

15. MARCOS MARTÍNEZ, A., "Reconstrucción de las pinturas barrocas de la fachada del Palacio del Marqués de Huarte en Tudela". Príncipe de Viana, Primer Congreso General de Historia de Navarra, anejo 11 (1988), pp. 333-337; Esparza, B., El palacio del marqués de Huarte. Pamplona, 1987, pp. 39-42.

16. AZANZA LÓPEZ, J. J., "El palacio y la casa señorial". GARCíA GAINZA, Ma. C., (coord.), El Arte en Navarra. Pamplona, 1994, vol. 2, pp. 433-448. 
las mansiones de mayor abolengo se impuso la tipología imperial. En este modelo de escalera quedaban garantizados los efectos escenográficos, no sólo por la solemnidad que otorgaba la fábrica sino también por los cambios de perspectivas, direcciones y puntos de vista que ofrecían. Ejemplos de ello los encontramos en el tramo de la diseñada en el palacio de los Mencos de Tafalla o en la escalera-patio del palacio del marqués de Huarte de Tudela. Un caso excepcional es el que se puede ver en el palacio de los Marqueses de San Adrián, también sito como el anterior en la capital ribera, que poseía una caja de dimensiones fuera de lo común decorada a su vez con bellas grisallas alegóricas de origen renacentista $^{17}$. Por su parte, en 1700 el virrey Domingo Pignatelli expidió una cédula otorgando a don Juan José Vizcaíno la facultad de agregar cuatro torres en los ángulos de su casa palacial de Miranda de Arga "por ser equiparación de lo que les corresponde a los reales palacios de su majestad". Asimismo a este Palacio de las Torres se le agregaría una caja de escalera con su media naranja y cadenas en la puerta pues "no es más que signo de casa privilegiada"1".

\subsection{Del castillo defensivo rural a la mansión residencial en la ciudad}

Poco a poco se observó una cristalización de la 'casas-palacio', cuyas primeras manifestaciones surgieron en el Quinientos. Como ya dijimos, las casastorre del siglo $\mathrm{XV}$, levantadas entre las revueltas y las luchas de bandos, casi nada tenían que ver -en apariencia al menos- con los palacios del XVII y XVIII. Si algo distinguía a los palacios renacentistas de las torres medievales era su carácter urbano. Estas casas señoriales, originarias en su mayor parte de las torres de linaje medievales, derivaron a las hermosas construcciones del siglo XVIII. Y es que, de una u otra manera los palacetes, en cada época, correspondían en su forma a las dos maneras más visibles de expresar el dominio dentro de una sociedad: la fuerza de las armas o el dinero.

Según Domínguez Ortiz, si algo había tenido la nobleza peninsular había sido, al contrario que la inglesa, una vocación urbana ${ }^{19}$. En el siglo XVI, con la pacificación del territorio este movimiento se intensificó a pesar de que el éxodo rural no fue ni mucho menos rápido y total. Las nuevas mansiones urbanas de la alta nobleza navarra venían a ser residencias señoriales y sucursales de las prerrogativas y privilegios familiares alcanzados en los antiguos palacios de

17. GARCÍA GAINZA, Ma . C., (dir.), Catálogo monumental de Navarra. Merindad de Tudela, vol. I*. Pamplona, 1980, pp. 372-373.

18. Archivo General de Navarra [AGN], Nobleza, palacios de cabo de armería, leg, $1^{\circ}$., carp. 65. En el último testamento de Domingo Pignatelli, fechado en 1736, el edificio y sus añadidos estaban aún inacabados por lo que el noble dedicó una capítula con objeto de poder reservarse una buena cantidad de su patrimonio a tales labores arquitectónicas. ECHEVERRÍA GOÑI, P. L., Miranda de Arga, entre el Gótico y el Barroco. Miranda de Arga, 1983, p. 36.

19. DOMínGUEZ ORTIZ, A., La sociedad española en el siglo XVII. Granada, 1992, I, p. 275. 
armería rurales. Por ello, la casa levantada en la ciudad heredaba el escudo de la vieja fortaleza del campo, que continuaba siendo habitada por los caseros o 'claveros' que cuidaban también los privilegios que ésta poseía en el lugar. Nos encontramos así con las casonas de los Guenduláin, Ezpeleta, Rozalejo y Navarro-Tafalla en Pamplona o las de los San Cristóbal y los Eguía en Estella. Las edificaciones residenciales de los linajes de Veráiz, San Adrián e IbáñezLuna en Tudela y los palacios de Granada de Ega y Valle-Santoro en Sangüesa. O, por último, los de Sonsierra, Guenduláin y Feria en Tafalla y las casas-palacio de los Ezpeleta y los Rada en Olite entre otras muchas.

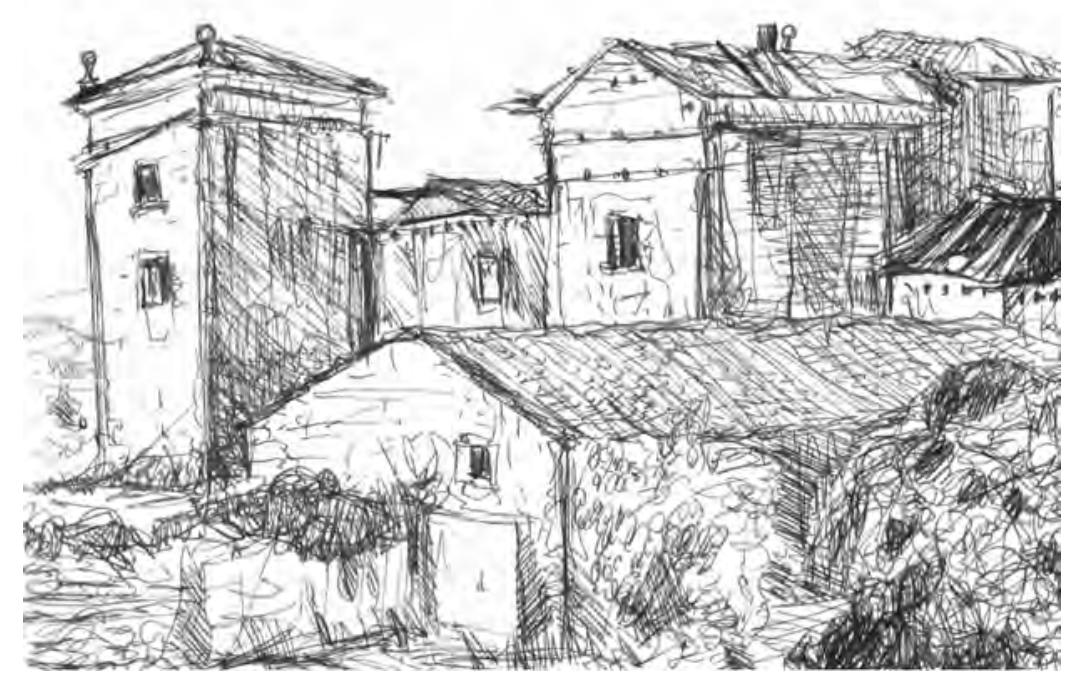

Figura 2: Palacio Jauregizar (Viguria) ${ }^{20}$.

A principios del siglo XVII, Juan Botero ya afirmaba que "no hay duda, sino que ennoblece mucho a la ciudad la residencia de los nobles, porque viven con más magnificencia, y gastan más que en él [sic] aldea". En el reinado de Felipe III la nobleza española construía en las urbes sus palacios al absorber estos núcleos de población toda la vida activa de la sociedad. Ligada la vivienda a la imagen y el prestigio familiar, la posesión u obtención de cualquier título

20. Fuente: Dibujo a pluma de Javier Álvarez Vidaurre. 2009. 
nobiliario pudo llevar aparejada la construcción de viviendas cerca de los centros de poder. A la par que los aristócratas se asentaban en lugares como Pamplona o Tudela, sus rentas, poder e influencia contribuyeron a aumentar la atracción de la población por la ciudad despoblando muchas regiones del agro. Poco a poco el lujo se adueñaba de las calles y las casas de los prohombres, no por ello nobles, residentes en la capital o en las cabezas de merindad. Fernández Navarrete en 1626 sentenciaba por su parte que "desechan por cortas personas de muy inferior jerarquía [...] siendo recíproca ocasión de gastos el tener grande casa, que pida muchas alhajas, o el cargar de alhajas, que necesiten de grandes casas [...] raya y límite a la ambiciosa soberbia de las fábricas, en que vemos, que roto el freno de la razón con el ímpetu de la voluntad, se juzgan estrechos en palacios muy grandes, los que pocos años antes se contentaban con muy limitadas comodidades ${ }^{21}$." Sin embargo, en las casas nobiliares se buscó además de la comodidad y la perpetuidad, la belleza. Ésta se convirtió en requisito indispensable y junto a la proporcionalidad se buscaba que el inmueble provocara contento a sus moradores e invitados además de placer y deleite a quienes lo contemplaran.

En el Reino los palacios se multiplicaron a finales del siglo XVII y principios del XVIII tras las pretensiones de grandes asentistas navarros que partiendo de supuestas hidalguías -colectivas o individuales- pretendieron más honras (marquesados, hábitos, etc.). Estos inmuebles eran producto de la fortuna de navarros con títulos nobiliarios recientes y adquiridos gracias a los servicios, normalmente económicos, prestados al monarca. Otras familias de rancio abolengo edificaron nuevas mansiones en sus lugares habituales de residencia. Así por ejemplo, los Goyeneche encargaron la construcción de un palacio en el centro de Madrid, cerca de la Puerta de Sol en el inicio de la calle Alcalá. El edificio fue trazado y construido por José Benito de Churriguera y su hijo Matías. Las obras, que comenzaron en 1724 en el solar de la llamada Casa de la Miel, no acabaron hasta 1730 alcanzando el elevado coste final de 1.841 .832 reales de vellón ${ }^{22}$.

El siglo XVIII fue una de las épocas de mayor auge y desarrollo urbanístico y monumental de Pamplona. Sin embargo, estas transformaciones en la capital navarra comenzaron en los últimos años del siglo XVII. Desde 1650 se crearon nuevos espacios urbanos transformando otros ya existentes e impulsándose a la vez la

21. FERNÁNDEZ NAVARRETE, P., Conservación de monarquías y discursos políticos sobre la gran consulta que el consejo hizo al señor rey D. Felipe III. Madrid, 1626, p. 243.

22. BONET CORREA, A.. "Juan de Goyeneche, su palacio y la Academia". GARCÍA GAINZA, Ma. C., (coord.). Juan de Goyeneche y su tiempo: los navarros en Madrid: ciclo de conferencias celebrado del 10 al 24 de marzo de 1999 en la Real Academia de Bellas Artes de San Fernando. Pamplona, 1999, pp. 15-48. 
arquitectura doméstica privada. Determinadas familias de las elites navarras se decidieron por construir sus residencias señoriales en las calles más notables de la ciudad. Es decir, en la calle Mayor, en la calle Zapatería y en la Plaza del Castillo, gran salón urbano así como lugar de encuentro y regocijo. Los promotores de estos monumentales edificios, vinculados a las casas principales de mayorazgo del Reino, tenían un denominador común: el origen de sus fortunas familiares era foráneo a la geografía navarra. Normalmente sus miembros habían hecho carrera en Indias o en la Corte, a lo largo de lo que se ha venido a denominar como la "hora navarra del siglo XVIII". Éste fue el caso de los Goyeneche, que edificarían su palacio en la Plaza del Castillo, los marqueses de Castelfuerte que lo harían en la calle Cuchillerías o los de San Miguel de Aguayo, que harían lo propio en la calle Mayor. La familia Navarro Tafalla edificó su residencia en la calle Zapatería junto con los Mutiloa. Por su parte, los Guendica lo hicieron en la Plaza de la Navarrería mientras que los Eslava, marqueses de la Real Defensa, lo harían en la calle San Francisco. A ellos se unió una pujante burguesía mercantil que quería ver respaldada su bonanza económica con el reconocimiento social en su tierra natal. De esta manera, dedicaron parte de sus cuantiosas fortunas tanto a la compra de ejecutorias de hidalguía como a potenciar su acceso a puestos relevantes del gobierno del Regimiento y a la construcción de grandes palacetes.

Sin duda alguna el palacio más importante de cuantos han llegado hasta nuestros días en Pamplona es el que erigió Pedro Fermín de Goyeneche en pleno siglo XVIII. No obstante, su padre, el baztanés Miguel de Goyeneche, fue quien en un primer momento decidió instalar la residencia familiar en la capital del Reino. Eligió para tal fin un edificio situado en la Plaza del Castillo abierto hacia la calle Estafeta. El inmueble lo adquirió en 1714 al vecino de Enériz don Fausto de Monreal e Iturbide ${ }^{23}$. Llegado el año de 1738 su hijo, el mencionado Pedro Fermín de Goyeneche, compró, al alcalde de Olite, el noble don Agustín Ezpeleta, una casa pegante tras obtener su dueño el permiso del Consejo Real dado que el edificio pertenecía al mayorazgo de Rada ${ }^{24}$. Tras cerrar la compra los Goyeneche procedieron al derribo de ambas casas para comenzar la edificación de su palacio cuyo coste final ascendió a 18.000 pesos ${ }^{25}$. La mansión situó su portada principal en la calle Estafeta, con el emblema familiar alojado

23. APNP, notario Pedro Miguel Urroz, Pamplona, 1735, 8-V.

24. AGN, TT.RR., Procesos judiciales, 48770 y APNP, notario Miguel Jerónimo de Elizalde, Pamplona, 1738, 11-XII.

25. Este desembolso situó como cabeza del mayorazgo de los Goyeneche un vínculo que fue fundado con carácter electivo. ANDUEZA UNANUA, P., "La Contribución de los hombres de negocios y comerciantes a la renovación arquitectónica de Pamplona en la primera mitad del siglo XVIII". V Congreso de Historia de Navarra, Grupos sociales en Navarra. Relaciones y derechos a lo largo de la Historia. Pamplona, (2002), pp. 71-82. 
en ella hasta que en 1847 los Rived, familia de prósperos comerciantes, compraron el palacio por el precio de 16.000 pesos $^{26}$.

En 1567 Vitrubio distinguía tres elementos básicos de cualquier construcción civil: firmitas, utilitas y venustas ${ }^{27}$. Este testigo fue recogido por diferentes arquitectos como Palladio o Alberti ${ }^{28}$. Éstos implantaron los ideales humanistas en sus construcciones durante el Renacimiento reordenando la concepción de la arquitectura palacial en toda Europa. La correcta distribución y la adecuada proporcionalidad de los elementos constructivos de un palacio suponían, además de belleza arquitectónica, un mensaje metafórico para todo aquél que accedía a su interior ${ }^{29}$. Por su parte, Alonso de Ledesma en sus Conceptos espirituales de 1600 presentaba las partes de la casona -escudo, portalón, bodega, tapia, pozo, pisos- como un ejemplo de orden simétrico y bien articulado ${ }^{30}$. En el mundo urbano la jerarquización del espacio interior de las viviendas se ejercía en varios sentidos y direcciones. La importancia de las estancias se reducía de adelante (las salas exteriores) a atrás (habitaciones interiores) y de la planta baja a la superior. El piso principal, normalmente situado en la primera planta, tenía los techos altos con más luz y ventilación y solía ser el ocupado por los señores. Por otro lado, las plantas inferiores acogían las bodegas, la cocina y el servicio doméstico. Este ideal de belleza palaciega también fue expresado por Ríos Hevia en un poema de 1615 dedicado a Santa Teresa con motivo de su beatificación: "bien cimentado, con hermoso frontispicio, con columnas, amplias ventanas, vidrieras, hermoso interior, paredes adornadas y, sellando todo ello, el nombre del dueño sobre la puerta ${ }^{31}$. . El valor estético conseguido merced a los elementos constructivos era de tal significación que en los contratos quedaban bien especificados. Así por ejemplo, en el contrato de la remodelación de 1704 del palacio de los Borda en Maya se señalaba que debería hacerse "a la moda y forma que tiene la casa concejil del Valle y Universidad de Baztán ${ }^{32}$ ". Es decir, aumentando su superficie y con austeridad y desnudez en sus paramentos que confirieran serenidad y elegancia al conjunto ${ }^{33}$. De esta forma la

26. APNP, notario Victoriano San Miguel, Pamplona, 1847, 2-VIII.

27. VITRUBIO, M., I Dieci Libri dell'Architectura. Milán, 1994, pp. 37-41.

28. ALBERTI, L. B., De re aedificatoria. Oviedo, 1975; Palladio, A., I Quattro libri dell'Architectura. Milán, 1945.

29. AZANZA LÓPEZ, J. J., "El palacio y la casa señorial...", p. 434.

30. LEDESMA, A., Conceptos espirituales y morales. Madrid, 1978, pp. 195-197 y 272 y ss.

31. RÍOS HEVIA, M. de los, Fiestas que hizo la insigne ciudad de Valladolid, con poesías y sermones en la beatificación de la santa madre Teresa de Jesús. Valladolid, 1645, p. 133.

32. APNP, notario Juan de Echeverz, 1703, 13-VI, contrato de las obras de carpintería.

33. ANDUEZA UNANUA, P., "La casa, la familia y los negocios en el siglo XVIII: Los Borda de Maya (Baztán)". Príncipe de Viana, 66 (2005), pp. 353-389. 
austera majestad de las portadas frente a la artificiosa sencillez de las fachadas, dominadas por los vanos y balconadas, convirtieron estas casas en un componente imprescindible del escenario urbano, e incluso en ocasiones del de las villas rurales. Los muros exteriores de las mansiones tendieron a homogenizarse, sobre todo en las calles propicias para los recorridos festivos y procesionales, respetando el más estricto clasicismo hasta bien entrado el Barroco $^{34}$.

Sin embargo, la sencillez exterior de las residencias señoriales no solía corresponder a una contención del lujo y la suntuosidad de los interiores. En el caso navarro la mayor parte de los palacios eran por fuera sencillos y sobrios en el trazo de sus fachadas. No obstante, si los comitentes pertenecían a capas de la nobleza más altas esta arquitectura residencial derivaba hacia lo monumental y lujoso. En ocasiones llegaban a darse situaciones de emulación entre convecinos poderosos ${ }^{35}$. Así por ejemplo, en 1769 en su testamento Pedro Fermín de Goyeneche dedicaba una cláusula a su nieta mayor María Josefa ${ }^{36}$. En ella señalaba que cuando la chica contrajo matrimonio con Joaquín de Rada y Mutiloa, el palacio de Subiza se hallaba inhabitable por lo que decidió derruirlo y reconstruirlo con la "grandeza y suntuosidad" que correspondía a familia tan distinguida ${ }^{37}$. Tengamos en cuenta que en los ambientes nobles el palacio era un índice de la prepotencia de la familia y el modo de vida nobiliar de la época requería lugares espaciosos para su desarrollo: salones, galerías, patios, etc. A la par, se deseaba cierta independencia entre los ámbitos donde se desenvolvía la vida de los señores y la del servicio ${ }^{38}$. En general la etiqueta alcanzó un lugar importante a la hora de diseñar la organización interna de estas casas nobiliares. Esto era así por lo menos en el caso de las mansiones de la alta aristocracia donde se hacía más que necesaria la existencia de un patio o una gran sala de recepciones central con cámaras privadas en sus extremos.

34. Tengamos en cuenta que la calidad de las casas de los nobles y el precio de sus solares estaba en función de su proximidad a los lugares más representativos y festivos de la ciudad: las plazas, las calles más importantes, las iglesias, etc. El precio del palacio no sólo dependía de su belleza sino también de lo que desde él se contemplaba. Cámara Muñoz, A., Arquitectura y sociedad..., p. 90.

35. BARRIO LOZA, J. A., "La arquitectura señorial...", p. 164-165.

36. APNP, notario Manuel Anchóriz, 1769, 30-VIII: últimas voluntades de Pedro Fermín Goyeneche.

37. ANDUEZA UNANUA, P., "El palacio de Subiza: Un palacio baztanés en la Cuenca de Pamplona". Príncipe de Viana, 64 (2003), pp. 59-90.

38. HEREDIA LAGUNAS, U., "Las casas palacio del siglo XVI en Zaragoza". Artigrama, 6-7 (1989-1990), pp. 81-114. 


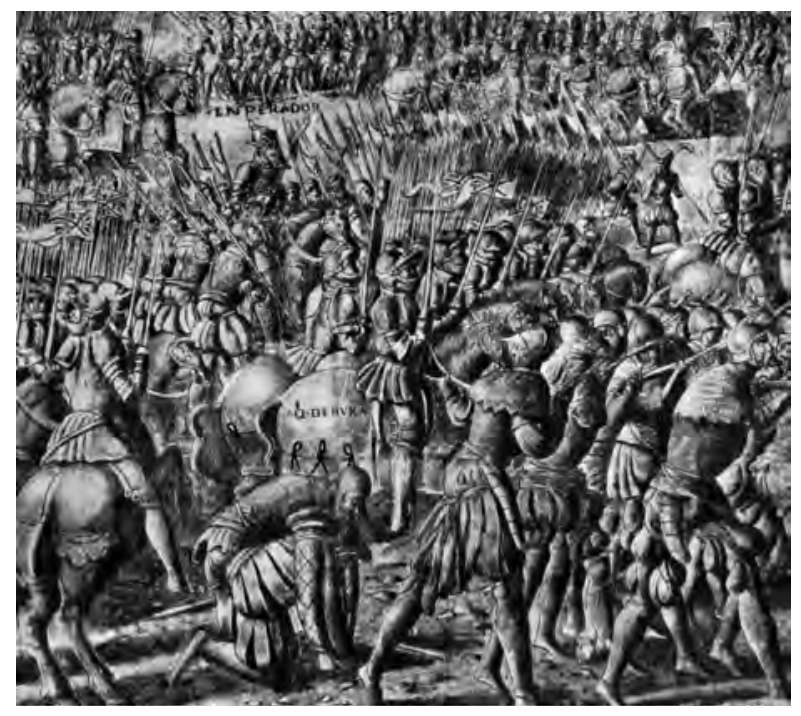

Figura 3: Sección de las grisallas del Palacio de Oriz ${ }^{39}$.

La grandeza de los interiores de los palacios venía vestida y adornada por tapices y colgaduras sustituidos desde comienzos del siglo XVII por cuadros. No obstante, en pleno siglo XVI el noble tudelano don Miguel de Eza, caballero de la Orden de Alcántara, decoró su casa con diferentes pinturas. Concretamente fueron "diez lienzos de Flandes guarnecidos de madera de un tamaño, y otros dos con dos bultos de mujeres ${ }^{40 "}$ ". Agustín de Rojas en su obra El viaje entretenido de 1603 escribía: "veo las pobres salas de mi soledad acompañadas y adornadas con la más rica tapicería del mundo ${ }^{41}$ ". El lujo llegó a ser un problema que supuso la aprobación de duras pragmáticas contra las colgaduras de brocado, telas de oro y plata, así como los bordados. Según Sempere y Guarinos, sólo se permitían las telas de terciopelo, damascos, rasos, tafetanes y seda prohibiéndose traer tapices de fuera con oro y plata ${ }^{42}$. En las descripciones del viaje a España entre 1576 y 1577 del rey Sebastián de Portugal siempre se

39. Fuente: SÁNCHEZ CANTÓN, F. J., Las pinturas de Óriz y la guerra de Sajonia. Pamplona, 1944, p. 41.

40. TARIFA, Ma. J., Miguel de Eza, humanista y mecenas de las artes en la Tudela del siglo XVI. Tudela, 2004, pp. 72-89.

41. ROJAS, A., El viaje entretenido. Madrid, 1964, p. 422.

42. SEMPERE GUARINOS, J., Historia del luxo y de las Leyes suntuarias de España. Madrid, 1973, pp. 99-100. 
observa una referencia a los tapices utilizados para adornar las estancias donde se alojó y que según el monarca enriquecían hasta el aposento más modesto ${ }^{43}$. Así pues, la decoración interna de una casa principal desde finales del siglo XV y a lo largo de la Modernidad estaba compuesta esencialmente por artesonados dispuestos para cubrir las diferentes estancias. A su vez, en ellas se podían encontrar tapices, guadamaciles y azulejos en las paredes así como alfombras, losetas de barro o piedra en los suelos ${ }^{44}$.

En materia decorativa, merecen una especial atención las grisallas que decoraban los muros del Palacio de Oriz (Valle de Elorz, Merindad de Sangüesa) cuyos señores eran los Cruzat. El palacio, flanqueado por cuatro torreones en sus esquinas poseía una escalera rústica aunque enriquecida en sus rampas con yeserías sembradas de armiños, que arrancaba desde el zaguán y conducía al piso noble. En los tramos de la escalinata se podían ver medallones, ventanas y el escudo de la familia en el rellano. La escalera terminaba en un vestíbulo alto decorado con un friso de pinturas y adornos en las sobrepuertas y encuadres de las ventanas con pasajes bíblicos. Posteriormente se abría una sala con un friso estrecho de niños desnudos que danzaban cogidos unos a otros de las manos con cascabeles en las pantorrillas. En la estancia inmediata, posiblemente el oratorio de la casa, existía un retablillo con la Visitación y a su lado una pintura de Cristo en la $\mathrm{Cruz}^{45}$. Finalmente se entraba en el gran salón de las Batallas donde se alojaban las famosas grisallas, pinturas murales realizadas al temple. Esta obra, claramente inspirada en grabados, debió ser ejecutada en torno al año 1550, atribuyéndose su autoría a Juan del Bosque ${ }^{46}$. En ellas se narran escenas bélicas de la Guerra de Sajonia librada por el emperador Carlos $\mathrm{V}$ contra los príncipes protestantes. Las imágenes concluyen con la victoria de Mülhberg, donde quizá el miembro de la familia don Diego Cruzat, capitán en los ejércitos del emperador, tomó parte ${ }^{47}$. Tengamos en cuenta que durante los siglos XVI y XVII las pinturas de guerras o hechos de armas tuvieron en la decoración de las galerías y las salas de los palacios una función conmemorativa. Su objetivo principal era dejar constancia de actos

43. PORTUGAL, S. de, El viaje a España del Rey. don Sebastián de Portugal. Valencia, 1956, pp. 87-92.

44. AGUILÓ, Ma . P., "Palacio y hogar. El mueble", García de la Concha, V., (et alii). Historia de España. XXI, La cultura del renacimiento (1480-1580). Madrid, (1999) pp. 127-152.

45. GARCÍA GAINZA, Ma . C., (dir.), Catálogo monumental de Navarra. Merindad de Sangüesa, vol. IV*. Pamplona, 1989, pp. 262-263.

46. SÁNCHEZ CANTÓN, F. J., Las pinturas de Óriz y la guerra de Sajonia. Pamplona, 1944.

47. Escenas murales similares acerca de la Batalla de Mülhberg se pintaron en el castillo de Alba de Tormes, de los duques de Alba. MARTINEZ DE IRUJO ARTÁZCOZ, L., La batalla de Mühlberg en las pinturas murales de Alba de Tormes, discurso del Señor Luis Martínez de Irujo y Artázcoz, Duque de Alba, leído en el acto de su recepción pública el 18 de marzo de 1962 y contestación del Señor Francisco Javier Sánchez Cantón, Madrid, 1962. 
dignos de ser recordados en los cuales, en numerosas ocasiones, habían participado los dueños de esas residencias señoriales. Eran escenas por lo tanto de carácter propagandístico y encargadas por los vencedores de aquellas batallas, que describían su fuerza y su heroísmo ${ }^{48}$.

En el siglo XVII, Miguel de Cruzat, prior de Roncesvalles y de la catedral de Pamplona, en sus últimas voluntades donó a su sobrino don Martín de Cruzat, señor del palacio de Óriz, sus bienes con la condición de fundar una capellanía de 2.000 ducados. Sin embargo, Martín murió a su vez sin haber consignado los bienes para la fundación, por lo que en 1684 eran reclamados a su viuda que los tenía en la residencia pamplonesa. En el inventario de los bienes de don Martín de Cruzat se anotan numerosos cuadros de pintura que decoraban las estancias de su casa: una Magdalena con marcos ordinarios, dos bodegones con marcos grandes y otros dos "menos largos", veintisiete cuadros de ermitaños, dos de "paisajes", dos de San Juan Bautista, dos retratos de don Tiburcio de Redín y otro de don Martín de Redín "Gran Maitre de Malta", un cuadro de San Joaquín con los de Santa Ana y la Virgen "menor", una escena de la Sagrada Familia, una pintura representando la oración en el Huerto de los Olivos con marco sobredorado, un cuadro de la Virgen con dos niños con la mano en el regazo, una pasión de Cristo con marco dorado, una obra pequeña con Cristo abrazando a San Francisco, una lámina con la oración de los reyes de Roma, una Verónica con el marco sobredorado, una lámina del Salvador y otra de la Virgen, otra más de alabastro en la que se representa el convite de los fariseos y la Magdalena, un cuadro pequeño cerrado de oratorio con sus dos ventanas de nogal y las pinturas de piedras de colores de la Pasión de Jesucristo, otra representación del mismo trance con marco dorado y más pequeña, un juego de cuadros con "los reyes nuevos" y sus bastidores, otro Cristo crucificado de gran tamaño, cinco cuadros más de diferentes tamaños de la Virgen y otros de Cristo, un retrato de San José y otro de Santo Tomás, un relicario con marco y dos relicarios sobredorados con cruces de pasta. A todas estas obras se unían las que le había donado su tío Miguel entre las que se encontraban diferentes Cristos, un San Jerónimo "de medio cuerpo", un San Sebastián, un San Felipe, un San Isidro, un San Miguel, una Virgen de Montserrat, una Santa Teresa de Jesús, una Verónica, un retrato de Carlos V junto a su mujer, otro de Felipe II también con su esposa, una imagen de Felipe III y su consorte, un cuadro de Felipe IV con sus dos mujeres, Baltasar Carlos y una infanta, una pintura del "príncipe don Carlos", un "infante cardinal", diez grandes paisajes y varios bodegones ${ }^{49}$. Cabe señalar que durante la Modernidad resultaba fácil conseguir

48. PORTúS, J., "Miserias de la guerra: de Brueghel a Velázquez". GARCíA, B, (ed.). La imagen de la guerra en el arte de los antiguos Países Bajos. Imagen, comunicación y poder. Madrid, 2006, pp. 3-27.

49. Archivo Diocesano de Pamplona [ADP], C/938- $\mathrm{n}^{\circ} 1$. 
retratos de turcos y romanos, en los que el parecido no era un requisito esencial. No obstante, más caras y difíciles de adquirir que estas imágenes que circulaban como series de estampas, eran aquéllas de personajes concretos. Tales retratos exigían la mano de un pintor con la suficiente maestría como para imitar los escasos modelos susceptibles de ser copiados. Los autores de estos retratos eran gentes cercanas a la Corte o a los círculos de poder y la posesión de estos cuadros indicaba el elevado estatus social de sus dueños. Además servían a quienes los encargaban para realzar la importancia de sus propios retratos familiares. Se encuentran así retratos de miembros de la casa de Austria en las colecciones de nobles y caballeros junto a otras obras de carácter personal o religioso como en el caso de las poseídas por los Cruzat.

Como ya hemos señalado, en el siglo XVI muchas de estas casas palaciegas resaltaban por lo austero de su aspecto externo. Sin embargo, su mobiliario interno comenzaba a alcanzar un papel importante en la escenografía de la categoría y del poder social de sus dueños. Por el contrario, en las cámaras utilizadas por los señores de los palacios navarros del siglo XVII el dosel adquirió un papel destacado. Esta pieza decorativa no faltaba por ejemplo en ninguno de los comedores de los nobles, sometidos a una rigurosa etiqueta borgoñona $^{50}$. Por su parte, el estrado era, como describía Covarrubias, una "pieza capaz y bien alhajada donde las damas recibían sus visitas. Tomaron su nombre de la tarima guarnecida de alfombra o tapete sobre la que se colocaban almohadas y cojines y para los hombres taburetes o sillas bajas ${ }^{51 "}$. Destaca de esta manera en el palacio del marqués de Huarte, ubicado en Tudela, el Ilamado "cuarto del estrado", lugar de recepción de las damas de la casa. La citada habitación tenía como ornato en yeso seis tarjetas en el zócalo y un florón coronando la bóveda, decorado en $\mathrm{orO}^{52}$. En cuanto al mobiliario que albergaban las casas nobles navarras, la cantidad y calidad del mismo eran datos indicativos del nivel socioeconómico de sus dueños. Por otra parte, la posesión de estos bienes no estuvo sujeta en el Reino durante la Modernidad a ningún tipo de restricción legal aunque sí de tipo económico. Su elevado coste y el reducido tamaño de las viviendas, a excepción de las grandes mansiones señoriales, no permitían la instalación en su interior de una gran cantidad de muebles. Los inventarios post-mortem y los testamentos revelan que las piezas de este tipo más frecuentes en las casas de los nobles navarros eran: bufetes, arcones, sillas, escabeles con cielos y doseles, mesas y objetos suntuarios como porcelanas, relojes o

50. Se denominaba 'dosel' al ornamento con cortinajes que se colocaba a la manera de techo sobre un asiento principal, trono o altar. AGUILÓ, Ma. P., "Mobiliario en el siglo XVII". Mueble español. Dormitorio y estrado. Madrid, 1994, pp. 103-132.

51. Citado por AGUILÓ, Ma. P., "Palacio y hogar. El mueble", GARCíA DE LA CONCHA, V., (et alii). Historia de España. XXI, La cultura del renacimiento (1480-1580). Madrid, (1999) p. 143.

52. ESPARZA, B., El palacio del marqués..., p. 27. 
espejos. Los materiales con los que estaban fabricados eran tan nobles como sus dueños, destacando la 'taracea' ${ }^{53}$, el ébano y el nogal en las maderas; el oro, la seda, los damascos y el cuero, negro y rojo, en las telas así como la plata y los esmaltes en otros objetos. El mobiliario y los útiles destinados al servicio eran de pino, badana, barro o lana. García Bourrellier apunta que en el palacio de Marcilla las estancias que servían de alojamiento para la servidumbre carecían de espejos, alfombras, jarrones e incluso mesas ${ }^{54}$. Tras la muerte del marqués Diego de Croy en su inventario se apuntaba que dichas habitaciones sólo contaban con un catre y su jergón, algún taburete o silla y un arca vieja para guardar la ropa.

En 1643 en el inventario post-mortem de la palaciana de Irurozqui, doña María de Jáuregui, además de diferentes ropajes, "casales", cabezas de ganado, tierras de labranza, viñas y Quiñónez, se hacía un repaso de los bienes que poseía la casa nobiliaria. Entre ellos se citaba la existencia de una bodega con cubas de vino, una cuadra, una "masadería", arcas para la ropa y las simientes, dos escudillas de madera, un jergón, diferentes sábanas, varias camas (dos con cortinas) y otra en la sala principal con cuatro pilares "sobre cielo" y las goteras de estameña de 'paño de roncal' verde y "en pendiente de lienzo andado [viejo]", siete calderas, un candelero pequeño, un restillo, doce platos de estaño, dos tajadores pequeños, varios almadraques y en la cocina un sin fin de útiles entre los que cabían bancos, sillas, "paletillas" para el fuego, candiles una jarra de estaño, del mismo material varias sartenes y un salero "con su cubierta"55. En el testamento de don Martín de Cruzat, señor de Oriz, se señala que en su casa ubicada en Pamplona había como elementos ornamentales dos floreros grandes "de altar", un dosel con galán de oro que al abrirse mostraba un crucificado, un doselete de verde y oro con cuatro relicarios, otro azul y plata con galán de plata, un espejo normal y otro grande de marco de oro y asa de plata de armas. El montante del mobiliario y menaje del hogar estaba compuesto por varias sillas, escritorios, tresillos, cofres, bufetes, arquillas, camas, 'mediacamas', taburetes, tarimas y además carretones, arcas, arquillas, veladores, armarios, tablas y tablones de cobre, rastrillos, diferentes útiles domésticos, celosías, ventanas nuevas de roble, portillas, puerta noble y literas, menaje de cocina y mesa e incluso un rosario de coral, diferentes joyas y ropajes de vestir y hogar ${ }^{56}$.

53. La 'taracea' era un entramado de chapa de maderas, en ocasiones pintada, que se podía mezclar con trozos de nácar, conchas y otros materiales.

54. GARCÍA BOURRELLIER, C. R., Nobleza titulada y organización señorial en Navarra (siglo XVII). Pamplona, 1998. Tesis doctoral inédita, p. 507.

55. AGN, TT.RR., Procesos judiciales, 149996, fols. 2-9.

56. ADP, C/938-n ${ }^{\circ} 1$. 


\section{Gusto y preeminencia en el vestir del Brazo Militar}

\subsection{El vestido y sus funciones}

Diferentes estudios centrados en la historia cultural europea han revelado la importancia de la vestimenta como signo de identidad de individuos y entidades colectivas o grupos sociales. Los cambios en las costumbres han afectado desde antiguo de manera muy visible al vestido, debido a que la indumentaria ha tenido una influencia decisiva en la evolución sociocultural y civilizadora del hombre ${ }^{57}$. Debemos tener en cuenta que los principales intereses que se satisfacen con la ropa son la protección de los rigores climáticos, la honestidad, el adorno y la identificación de la propia persona o grupo social. Casi se podría asegurar que no ha existido ningún grupo social en el que sus integrantes no hayan hecho un uso específico de algún tipo de ropaje, "incluyendo adornos y decoraciones corporales para distinguirse del resto de sus compañeros ${ }^{\prime \prime 58}$. Las telas y ropas han constituido no sólo una necesidad sino también un adorno externo simbólico. De esta manera, la vestimenta ha constituido un instrumento retórico de la representación de las relaciones de poder, división social, violencia o grado de civilización de una sociedad. Como arguye Bourdieu, las vestiduras no son sino una de las áreas de intercambio simbólico y de práctica sociocultural en donde los sistemas de dominación e interrelación encuentran su expresión: "taste classifies, and it classifies the classifier. Social subjects, classified by their classifications, distinguish themselves by the distinctions they make, between the beautiful and the ungly, the distinguished and the vulgar, in which their position in the objective classifications is expressed or betrayed"59. Es decir, la ropa ha servido para crear la imagen del individuo y su percepción por parte de sus contemporáneos.

Durante la Edad Moderna la importancia social del traje en la Europa occidental alcanzó un papel relevante ${ }^{60}$. La ropa durante el Antiguo Régimen contuvo

57. DÍEZ FERNÁNDEZ, I., "Libertad de percepción y realidad variable: algunas notas sobre la semiología del vestido en el Quijote". Anales cervantinos, 34 (1998), pp. 61-83.

58. MELÉNDEZ, M., "La vestimenta como retórica del poder y símbolo de producción cultural en la América colonial: de Colón a El lazarillo de ciegos caminantes". Revista de Estudios Hispánicos, 29 (1995), pp. 411-439.

59. BOURDIEU, P., The field of cultural production: Essays on literature and art. Columbia, 1993, p. 2.

60. Así lo demuestran los diferentes tratados del 'arte del vestimento' que se publicaron en la Europa moderna, con la intención de estandarizar y economizar costes en la producción de ropajes. De todos ellos podemos destacar, entre otros, el escrito de 1550 redactado por el hidalgo alavés Juan de Alcega con el título de Libro de Geometría y traça por su carácter precursor en la sastrería de la Monarquía hispánica y la extracción social de su autor. PUERTA ESCRIBANO, R. de la, "Los tratados del arte del vestimento en la España moderna". Archivo Español de Arte, 293 (2001), pp. 45-65. 
un importante sistema codificado, con distintos niveles de distinción correspondientes a diferentes estamentos sociales y profesionales. Así, existía una relación directa entre el traje y la estructura social, entre su diseño y su simbolismo y las diferentes categorías identitarias que acogían el individuo. Categorías referentes a los estados civil, eclesiástico y militar, profesional, social, de género o de linaje, cuyas leyes todos conocían, quedaban determinadas por el uso o prohibición de determinadas telas y colores según el estatus social de la persona. De acuerdo con Bernis, "cuando los contemporáneos de Cervantes opinaban sobre las diferencias que se debían guardar en el vestir según la condición social de cada cual, distinguían dos categorías: las personas principales por una parte y las gentes comunes y ordinarias por otra". No obstante, matiza la autora, "el traje no siempre reflejaba claramente las diferencias sociales, pues las gentes comunes trataban de imitar en el modo de vestir a las principales" ${ }^{\prime \prime 1}$.

\subsection{La honra en el vestir}

Para el hombre que vive en comunidad el traje constituye un elemento anexo pero esencial a su personalidad ya que, según Deslandres, "manifiesta su lugar en el universo propio"62. En una sociedad cuya vida diaria venía marcada, como ya señalamos, por el honor y el cuidado de la honra, el vestido cobraba un valor especial como defensor de la honestidad ${ }^{63}$. Según la filosofía cristiana del momento el sentimiento de pudor, el cubrirse si no todo el cuerpo sí determinadas partes del mismo con ropas era una consecuencia del pecado original ${ }^{64}$. Antes de comer la manzana "estaban desnudos, el hombre y su mujer, sin avergonzarse de ello" (Gen. 2.25). Sin embargo, tras degustar el fruto prohibido "abriéndose los ojos de ambos, y viendo que estaban desnudos, cosieron unas hojas de higuera y se hicieron unos cinturones" (Gen. 3.7). La misma idea la recogió San Pablo en su primera carta a los Corintios (12.23) recordando que "a los miembros que parecen más viles los rodeamos de mayor honor y a los que tenemos por indecentes los tratamos con más decencia. Al contrario, nuestras partes honestas no han menester nada; pero Dios ha puesto orden en el cuerpo, honrando más lo que de suyo es menos digno de honor". No es por ello de extrañar que entre los elementos que según Colón hacían de la Española una "maravilla" merecedora de ser descrita se debiese destacar que "la gente de esta isla y de todas las otras que he fallado y habido no haya habido noticia, andan

61. BERNIS, C., El traje y los tipos sociales en el Quijote. Madrid, 2001, p. 359.

62. DESLANDRES, Y., El traje. Imagen del hombre. Barcelona, 1985, p. 189.

63. ORDUNA PORTÚS, P., Honor y cultura nobiliaria en la Navarra moderna (siglos XVIXVIII). Barañain, 2009, pp. 37-64.

64. PÉREZ MARTíN, A., "El derecho y el vestido en el Antiguo Régimen". Anales de Derecho, 16 (1998), pp. 261-289. 
todos desnudos, hombres y mujeres, así como sus madres los paren, aunque algunas mujeres se cobijan un solo lugar con una foia de yerba o una cosa de algodón que para ello hacen"65.

Era de esperar por lo tanto que las leyes referentes al vestido durante el Antiguo Régimen tuvieran como objeto preferente la protección de esta honestidad. Así por ejemplo en un auto fechado el 13 de abril de 1639 se prohibía a las mujeres, "de cualquier estado o calidad", Ilevar 'guardainfantes' y "jubones que llaman escotados salvo las mujeres que públicamente ganan con sus cuerpos y tienen licencia para ello, a las cuales se les permite que puedan traer dichos jubones y con el pecho descubierto, y a todas las demás se les prohíbe dicho traje $^{\prime \prime 66}$. En 1723 Felipe V mediante una pragmática volvió a encargar a los obispos y prelados que procuraran corregir los excesos de las modas escandalosas en los trajes de las mujeres. Les hacía saber que podían recurrir incluso si lo veían necesario al Consejo, que tenía ya orden de prestarles auxilio para tal fin. Una disposición similar se contenía también en una pragmática de 1783.

Otra preocupación de las autoridades era la de evitar que determinadas indumentarias facilitasen la realización de delitos enmascarando el rostro. La primera de las disposiciones volvió a volcarse en el sexo femenino, y en los hombres travestidos como mujeres, a los cuales se les prohibió andar con el rostro cubierto debido a que "de ello han resultado grandes ofensas a Dios y notable daño a la república, a causa de que en aquella forma no conoce el padre a la hija, ni el marido a la mujer, ni el hermano a la hermana y tienen libertad y tiempo y lugar a su voluntad, y dan ocasión a que los hombres se atrevan a la hija o mujer del más principal, como a las del más vil y bajo"67. En los años 1590 y 1639 se volvió a insistir en lo mismo y desde 1716 a 1804, esta prohibición se extendió a todos los súbditos en general sin excepción de sexo, estado o calidad. Fue en 1766 cuando mediante una Real Orden se ordenó sustituir la capa larga y el sombrero redondo, el chambergo, la montera y el embozo en la Corte y Reales Sitios así como en los lugares públicos en general. Se aconsejaba en su lugar la capa corta y el sombrero de tres picos ${ }^{68}$.

Tiempo atrás, en el Medioevo, las mismas Partidas, refiriéndose a los caballeros, señalaban que "otro sí deben también sus paños, como las armaduras e armas que trajeren, hacerlas hermosas e apuestas a pro de sí, de manera que parezcan bien a los que las vieren, e sean ellos conocidos, así que se aprovechen

65. COLÓN, C., Textos y documentos completos: relaciones de viajes, cartas y memoriales. Madrid, 1989, p. 141.

66. PÉREZ Y LÓPEZ, A. X., Teatro de la legislación universal de España e Indias. Madrid, 1792, XXVIII, p. 152.

67. Novíssima Recopilación de las Leyes del Reino de Navarra [NR]. Pamplona, 1964, 6, 13, 8.

68. NR, supra n. 1, 6, 13.14. 
de ellas e de cada una según aquello para que fue hecha. E otrosí deben ser de buena barata. Ca si lo non fuesen todo su guisamiento non les valdría nada, e serían atales los que esto hiciesen según los sabios antiguos dijeron, como el árbol sin corteza, que parece mal e secase ayna" (Las Siete Partidas, supra n. 2, 2.21.22 y 2.21.13). Ya durante el Antiguo Régimen se admitía en la Monarquía hispánica que uno de los fines del vestido era el adorno de la persona, de acuerdo con su condición social. No obstante, estaba prohibido el lujo en exceso. En 1788 Juan Sempere y Guarinos definía aún el lujo "como se entiende generalmente y como yo creo que debe entenderse, esto es, el uso de las cosas necesarias para la subsistencia, por vanidad o voluptuosidad, es malo, que es un vicio detestable, como todos los demás"69. Es por ello que casi toda la legislación secular referida a la vestimenta tuvo como uno de sus objetivos el corregir el exceso de lujo. Estas diatribas, decretos y prohibiciones, aunque bien intencionadas y en parte aplicadas con rigor, carecieron de la eficacia y la ejemplaridad necesaria, ya que los notables y cortesanos eran los primeros sobre los que podían caer aquellas condenatorias recriminaciones ${ }^{70}$. En el Renacimiento la pasión de vestir con riqueza deslumbrante se había apoderado ya de la nobleza, llegando los nobles hispanos a extremos insuperables representando los ropajes en el presupuesto familiar el capítulo más costoso. A mediados del siglo XVI Alejo de Venegas, en su libro Agonía del tránsito de la muerte, señalaba que el primer pecado de los súbditos del rey español era "el exceso de los trajes, cuales por exceder extraordinariamente al caudal ordinario de la renta o hacienda, engendran ordinarias trapazas y pleitos, por cuya causa están las ciudades afianzadas: y ese poco de la hacienda que había de andar como en rueda del mantenimiento de casa se va en las audiencias".

En Navarra ningún aspecto de la vida cotidiana escapaba a la atención legislativa de sus Cortes, incluso los detalles que a primera vista podían parecer triviales como los relativos a la indumentaria. El título XII del libro III de la Novíssima Recopilación de Leyes del Reino, bajo el epígrafe De los trajes, vestidos, espadas y armas prohibidas, recogía una serie de leyes sobre el lujo en el vestir. En el año 1565 en las Cortes de Tudela, se aprobó dicha pragmática que ponía límites a la generalización del uso de atuendos lujosos en tierras navarras:

Ninguna persona, hombre ni mujer de cualquier calidad, estado, condición, y preeminencia que sea, pueda traer, ni vestir ningún género de brocado, ni tela de oro, ni de plata, ni en ropa suelta, ni en aforro, ni en guarnición, ni en jubón, ni en calzas, ni en gualdrapas, ni en guarnición de muía, ni caballo, ni de otra manera;

69. SEMPERE GUARINOS, J., Historia del luxo..., pp. 21-22.

70. PFANDL, L., Cultura y costumbres del pueblo español de los siglos XVI y XVII: Introducción al estudio del Siglo de Oro. Madrid, 1994, p. 270. 
y que esto se entienda asimismo en telas y telillas de oro y plata falsas, y en telas y telillas barreadas y tejidas, en que hay oro y plata, aunque sea falsa.

Ítem, que ninguna persona, de ninguna condición, estado, ni calidad que sea, pueda traer ni traiga en ropa, ni vestido, ni en calzas, ni en jubón, ni en gualdrapas, ni en guarnición de muía ni de caballo ningún género de bordado ni de recamado, ni gandujado, ni entorchado, ni chapería de oro, ni de plata, ni oro de canutillo, ni de martillo, ni ningún género de trenza, ni cordón, ni cordoncillo, ni franjar ni pasamano, ni pespunte, ni perfil de oro, ni de plata, ni de seda, ni otra cosa, aunque el dicho oro y plata y sedas sean falsas.

Ítem, que no se pueda traer, ni traiga en ninguna ropa, ni vestido, ni ninguna de las otras cosas susodichas ningún genero de colchado, ni prensado, ni raspado; ni se puedan en las guarniciones que por esta premática se permiten de seda ni de paño, hacer cortadura, brosladura o carpadura, ni deshilado, aunque se podrían acuchiIlar las dichas guarniciones.

Ítem, que en ningún género de vestidos de hombres ni mujeres se pueda traer guarnición de mas de una faja de una ochava de vara de Navarra de ancho; en la cual pueda llevar dos pespuntes del uno al un orillo, y no más; o, en lugar de la faja, tres ribetones o fajas, con un pespunte cada ribetón por medio, que no tengan todas tres juntas más de seda y paño cuanto una sexta de vara de Navarra. Y la faja y ribetones se puedan acuchillar, con que no sea raspado, ni deshilado, ni de cortado, que haga labor; y en las capas y capotes puedan traer por de dentro de raso, o terciopelo, y tafetán una faja, que tenga ochava, y no más. Y esta manera de guarnición se entienda, que no se pueda traer si no fuere en delantero y alrededor, sin traviesa, ni de por medio, ni en braones de mangas. $Y$ esto se entienda en cualquier vestido, así de paño como de seda.

Ítem, que en las ropas sueltas de hombres y mujeres, de terciopelo y raso, se permite, que tan solamente puedan aforrarlas en tafetán, y no en otra seda. Y que los jubones de raso se puedan pespuntar, con que el pespunte no haga labor.

Ítem, que no se pueda traer en jubones, ni cueros, ni en otra ninguna manera de vestido, telillas, con oro ni plata, aunque sea falso, ni cosa de hilo de oro ni plata, sino fuere tan solamente escofiones, que se permite a doncellas y mujeres recién casadas o desposadas. $Y$ estas tales casadas o desposadas no mas de dos años, contados del día que se desposaren. Y en los tales escofiones de hilo de oro y plata, no puedan traer perlas sino solamente en el pretín por medio de la cabeza, y en orla de toca hacia la frente; pero que puedan traer toda cosa de oro de martillo y de plata, así hombres como mujeres.

Ítem, que en sayos, sayas, capas, ropas sueltas de seda y paño, se puedan traer un ribetón de felpa de seda, con que no sea el dicho ribetón en todo mas que media ochava de vara de Navarra, y sólo en un ribetón o faja, y no más.

Ítem, que no se puedan traer calzas guarnecidas de seda ni de paño, sino solo con un aforro de paño, o lienzo demás de los tafetanes; los cuales puedan echar de la seda que quisieren. De manera que las dichas calzas no tengan ninguna manera de follaje; y que las cuchilladas se puedan aforrar en bocací o fustán, con que no se les eche seda. 
Ítem, que no se puedan dar libreas a pajes ni lacayos en que haya ningún genero de seda ni guarnición de ella, sino solamente puedan traer gorras de seda; y la guarnición de paño no sea más de una ochava de vara de Navarra en ancho, sin pespunte ni manera de labor.

Ítem, que en los sombreros se puedan traer por el orillo un pasamanos, o trenza de oro y plata, y cordón o trenza alrededor.

Ítem, que en guarnición de caballos o muías, se pueda traer una franjuela o flocadura de seda, y botones en rienda, excepto a la jineta, que puedan traer cualquier jaez.

Ítem, que los que trajeren las dichas ropas contra lo proveído y mandado y ordenado en estas Leyes y Premáticas, de cualquiera calidad y condición que sean, hayan perdido y pierdan la dicha ropa, con más otro tanto del valor y estimación de ella. Y para obviar algunos fraudes y composiciones, y otros modos y formas que podrían suceder y se podrían tener con los Jueces y otras personas, se mande: que la ropa que contra esta Premática se trajere, que conforme a lo dicho está perdida, se aplique a obras pías, como a Iglesias y Hospitales o Monasterios; y que no puedan quedar ni dejarse en ninguna manera a las partes, ni a otras personas, ni se pueda usar de ellas contra el tenor de la dicha Premática. Y en cuanto a la estimación, aquella se haga con oficiales verdaderamente y con juramento delante del mismo Juez, sin que cometa a otras personas. Y que de lo que así montare no se pueda hacer moderación ni remisión alguna, sino enteramente se ejecute, aplicándolo por tercias partes a la Cámara y Fisco, y Juez, y denunciador. So pena, que el Juez que así no lo hiciere y cumpliere, pague el cuarto tanto de lo que así valiere: las dos tercias partes para la Cámara y Fisco, y la otra tercera parte para el denunciador.

Ítem, que los Sastres, Jubeteros, Calceteros y Oficiales, y otras cualesquiera personas que cortaren, e hicieren, e intervinieren en hacer las semejantes ropas contra lo contenido en esta Premática, ahora las hagan dentro del Reino, o saliendo a hacerlo fuera del Reino para las tomar a él: por la primera vez, incurra en dos tanto de la estimación y valor de la tal ropa, aplicando la tal pena, por la manera que dicho es, por tercias partes. Y sea a mas de esto desterrado por dos años del Lugar donde fuere y residiere; y por la segunda, sea doblada la pena aplicada por la manera dicha, y desterrado por cuatro años del Reino; y por la tercera, pierda la mitad de sus bienes, para la Cámara y Fisco, y sea desterrado perpetuamente.

Ítem, que los vestidos, que están hechos hasta ahora se puedan traer y usar; los de los hombres por dos años y los de las mujeres por tres años, desde el día de la publicación en adelante; y en el dicho tiempo de los tres años, a las mujeres no se les puedan quitar, ni ejecutar, y a los hombres en el dicho tiempo de dos años.

Ítem, que los extranjeros que vinieren fuera del Reino a este Reino y trajesen vestidos contra lo proveído en esta Premática, puedan usar de ellos por seis meses, con que no puedan hacerlos en este Reino; y entendiendo ser extranjeros los de fuera de España.

Ítem, por evitar muchos enojos y escándalos que podrían suceder en entrar los ejecutores en las dichas casas a escudriñar los vestidos contra esta Premática, se ordene: que no entren en las dichas casas; pero que por denunciación se pueda 
recibir información, y constando por ellas se ejecute la pena, y compelan a dar el vestido para que se aplique conforme a la Premática ${ }^{71}$.

La ley generó multitud de protestas lo que supuso que en las Cortes de EsteIla de 1567 se prorrogara el plazo de moratoria de los vestidos lujosos "hasta que se gasten" ${ }^{\prime \prime 72}$. Y de nuevo se volvería a prorrogar en 1569 esta disposición "porque los más vestidos y trajes, que al tiempo estaban hechos, especialmente los de las mujeres no están gastados, no se gastarán en muchos años, y conviene se dé de nuevo prorrogación para ellos"73. Martínez Arce apunta que finalmente esta medida se suavizó ${ }^{74}$. De esta manera, finalmente se permitió que los trajes guarniciones de hilo que no fueran, eso sí, de seda u oro ${ }^{75}$. De hecho, en las Cortes de Pamplona de 1572 se asumía necesario moderar la ley del sesenta y cinco ya que la economía del Reino pasaba por buen momento. Así, se aprobaron excepciones como "que ninguna persona, ni personas de la gente de guerra, ni sus mujeres ni familias puedan ser comprendidos en ningunas de las cosas sobre dichas, tocantes a esta reformación de trajes y vestidos" ${ }^{\prime \prime 7}$.

En Navarra a su vez, en el cuaderno de leyes de 1621 una pragmática regulaba "las fiestas generales de torneos, sortijas y otras cosas" y en ella se alegaba que debido "los gastos que se hacen en las ocasiones de fiestas generales y públicas que se ofrecen en este Reino, son tan excesivos y grandes, que obligan a que se mire atentamente por el remedio de este año, para que excusándose, puedan los caballeros ejercitarse en semejantes fiestas, con la moderación de las galas y gastos, que de aquí adelante se hubieren de reformar"77. Con tal objeto se redactaron en los siguientes términos las órdenes que, quien contraviniera, pagaría con cincuenta ducados "por mitad para nuestra Cámara y Fisco, y denunciante":

Primeramente, que en los torneos de a pie que se hicieren en este Reino, ninguna persona de ninguna calidad, condición, o estado que sea, pueda sacar en calzas y torneletes, sino en Bocací de colores, lienzo, o paño de hasta ocho reales de vara.

Que no puedan Ilevar sobrepuestos ninguno, sólo que en los cantos de las cuchillas y toneletes puedan echar franjilla, o floquecillo de hiladillo.

71. Cortes de Tudela, 1565, ley 49.

72. Cortes de Estella, 1567, ley 24.

73. Cortes de Pamplona, 1569, ley 13.

74. MARTíNEZ ARCE, Ma . D., "Leyes, modas, usos y costumbres. Curiosidades de la legislación navarra emanada de las Cortes (siglos XVI y XVII)". VI Congreso d Historia de Navarra. Navarra: memoria e imagen, vol. I (2006), pp. 351-363.

75. Cortes de Pamplona, 1569, provisión 2.

76. Cortes de Pamplona, 1572, tras la ley 3, fol. 12.

77. Cortes de Pamplona, 1621, ley 64. 
Que no puedan meter en ninguna cosa seda, oro, plata, falsa, ni fina.

Que en las celadas no puedan llevar el mantenedor, sino doce plumas, y los aventureros a cada ocho plumas, y que los unos ni los otros no puedan Ilevar martinetes, ni garzotas, aunque sean de vidrio, ni argentería falsa, ni fina.

Que en ninguna cosa puedan echar ni sacar lentejuelas falsas, ni finas.

Que no puedan dar librea a criado ninguno.

Que a las Cajas, Pífanos y Trompetas no se puedan tampoco dar libreas, sino vaqueros de Bocací, lienzo, o paño de siete a ocho reales de precio, y bandas de sus colores de hasta vara y media cada una de tafetán sencillo, Ilanas, sin franja, rapacejos, ni puntas de ninguna cosa.

Que a los Padrinos se puedan dar bandas de tafetán, sin puntas, rapacejos, ni franjas, y que cada una de ellas pueda ser de tres varas.

Que el mantenedor de esta fiesta no pueda sacar sino cuatro Cajas y dos Pífanos, y los aventureros a dos Cajas y un Pífano.

Que si mantenedor y aventureros quisieren salir a la plaza a donde se hubiere de hacer esta fiesta, puedan sacar hasta doce Cajas y seis Pífanos; pero que si hubieren de salir cada uno de por sí, se haya de guardar la orden del capítulo anterior.

Que en fiestas de Justas, o Torneos de a caballos, o Sortija, en lo que es las galas, se guarden las condiciones y reformación que en el Torneo de a pie, excepto que el mantenedor de estas fiestas de a caballo pueda vestir dos lacayos, conforme a las condiciones y Premática del Torneo de a pie; y los aventureros, un lacayo cada uno en la misma forma.

Que no pueda meter el mantenedor más de dos Trompetas y dos Atabales, y los aventureros a cada una Trompeta.

Que ningún mantenedor de estas fiestas de a caballo pueda hacer otro gasto ni sacar ninguna invención, excepto si quisiere pueda tener Chirimías para cuando hayan de entran los aventureros.

Que los mantenedores puedan meter en las testeras de los caballos tres plumas, y que ni ellos, ni los aventureros lleven remate de plumas en los paramentos, y que los dichos aventureros puedan llevar tres plumas en las cabezas y el mantenedor cinco.

Que los dichos mantenedores no puedan meter tras de sí caballos con paramentos, ni sin ellos, sino en los que entraren, que para cuando hubiere de haber juego de Cañas, no puedan vestir criado ninguno.

Que las libreas de las cuadrillas no puedan ser de otra cosa que de tafetanes, y si quisieren echarles algunas franjas, no puedan sino de hiladillo y media seda, sin que lleven, ni puedan Ilevar sobrepuesto ninguno, porque si quisieren llevar dos o tres colores de tafetanes ha de ser trepándolos, y que no sea con sobrepuestos.

Que no puedan llevar en ninguna cosa oro, ni plata falsa, ni fina.

Que ninguno pueda llevar en el bonete más de cinco plumas.

Que la dicha Premática y reformación de galas no se entienda en las venidas de los Señores Reyes a este Reino. 
Sancho aconsejaba de esta manera a su mujer: "vístelo [al Quijote] de modo, que disimule lo que es y parezca lo que ha de $\operatorname{ser}^{\prime \prime 78}$. Si atendemos a las palabras que nos dejó escritas en 1563 Fray Tomás de Trujillo en su Libro Ilamado reprobación de los trajes y abuso de juramentos publicado en EsteIla, podemos percibir la importancia que llegó a adquirir el ropaje en esta época ${ }^{79}$. La manipulación de la ropa implicó no solamente una modificación de la escala diferencial en el vestir entre las clases sociales, sino también, dentro de los guardarropas individuales, la posibilidad de asumir diferentes identidades mediante el disfraz o el uso indebido de algunas prendas: "Desapruebo tantas diferencias de ropas: unas para la plaza, otras para la casa; unas para levantar, y otras para rezar; unas para el camino, y otras para la posada [...] pareciendo unas veces montero, otras caballero; unas soldado, otras médico; unas labrador pobre, otras ciudadano rico; como representador de muchos dichos en una sola comedia". En tales casos, la identidad se convertía en un funcionamiento, una forma de auto-presentación, no obstante condicionada y en cierto grado controlada por las fuerzas externas tales como códigos del vestido, abundancia personal, y la disponibilidad de ciertos materiales. Fue claramente el peligro de debilitamiento de la frontera entre una categoría social y otra lo que ocasionó esfuerzos por parte de las autoridades, con objeto de regular la exhibición y aparentemente la posesión de la ropa y otros adornos corporales ${ }^{80}$. Y es que la manipulación del traje adquirió diferentes formas desde el Renacimiento. La tela, los colores, y los estilos implicaban connotaciones de tipo cultural y social que limitaban su uso a los portadores imponiendo restricciones y obligaciones ante el mismo. Tengamos en cuenta que la percepción del ser humano es libre por lo que el disfraz debe ser considerado el medio empleado durante la Modernidad para transformar la realidad personal, engañosamente, ante el otro. Se introdujo un elemento nuevo perturbador de la libre percepción: la voluntariedad ajena. De esta manera, la percepción imaginativa quedó suplantada o reorientada en un sentido determinado ${ }^{81}$.

\subsection{La moda de la nobleza navarra durante la Modernidad}

En el estudio de la ropa de la Edad Moderna los inventarios post mortem resultan una fuente útil, aunque estas escrituras notariales recogen más

78. CERVANTES SAAVEDRA, M., El ingenioso hidalgo Don Quijote de la Mancha. Madrid, 1948, tomo III-IV, segunda parte, cap. V, p. 138.

79. TRUJILLO, T., Libro llamado reprobación de los trajes y abuso de juramentos, Estella, 1563.

80. DONAHUE, D., "Dressing up and dressing down: clothing and class identity in the Novelas ejemplares". Cervantes: bulletin of the Cervantes Society of America, 24 (2004), pp. 105-118.

81. DÍEZ FERNÁNDEZ, I., "Libertad de percepción...", p. 72. 
menciones a las telas del hogar -cama, mesa, etc.- que a prendas de vestir. En los recuentos y registros de guardarropas es difícil encontrar descripciones detaIladas de la indumentaria tanto masculina como femenina. Los inventarios de bienes para el caso de los vestidos, en el mejor de los casos especifican si eran de diario o de fiesta sin dar más detalles, lo que impide el análisis de aspectos tan interesantes como la tipología del mismo o los tejidos y colores predominantes $^{82}$. Cuando se hace referencia a las joyas que se poseían las descripciones sí que son más detalladas. En el inventario de la casa Echeverz de Pamplona, realizado en 1717, se enumeraban varias joyas con numerosos brillantes y otras piedras $^{83}$. Asimismo, la riqueza en el vestir de la casa venía reflejada por diferentes tapices -con relatos clásicos como el de Sansón, el de Alejandro y el incendio de Troya; o con motivos religiosos como la procesión del Corpus-, colgaduras en telas ricas como el damasco, seda, tafetán o doradas; así como esteras y alfombras de China, Sicilia y Turquía ${ }^{84}$.

Doña Teresa de Rada, viuda y heredera de don Martín Cruzat y Góngora, señor de Oriz y Góngora poseía en 1684, entre un sinfín de objetos suntuarios de gran valor, una serie de joyas entre las que destacaban las esmeraldas, el oro y diferentes cristales, así como mantillas con brocados y gargantillas ${ }^{85}$. Otro ejemplo lo encontramos en el inventario de bienes de don Fernando de Baquedano, señor de Gollano, fechado en 1630 donde se mencionaban por su parte una cadena, una sortija de diamante, otra de oro y un collar de oro, herencia de su madre; una pieza de oro, una sortija de oro, una cadenilla o lazarán de una vuelta y un crucifijo todo de oro y obtenido en el matrimonio, un "agnus" de oro, 150 botones de oro, un trencillo de oro para su sombrero, abundante ropa de cama vieja de sus padres y otra más nueva, manteles, sábanas, camisas, toallas y diferentes vestidos no descritos ${ }^{86}$.

Entre las telas, vestidos y ropas -cuyas características no se especifican- y joyas que se registraron en la descripción de bienes de 1626 de la familia Cruzat podemos citar: una cadena de oro esmaltada de "piezas de media luna", tres cadenillas de oro "de lustre", cortinas de gasa de la India y otra de "pepetuana turquesada", una más de escarlata carmesí y una última de paño azul, seis almohadas de terciopelo azul con asientos de Damasco, una alfombra grande, todos los vestidos de doña Catalina de Feloaga y de su hija doña Mariana de

82. SOBRADO CORREA, H., "Los inventarios post-mortem como fuente privilegiada para el estudio de la historia de la cultura material en la Edad Moderna". Hispania, 3, 215 (2003), pp. 825-862.

83. ANDUEZA UNANUA, P., La arquitectura señorial de Pamplona en el siglo XVIII. Familias, urbanismo y ciudad. Pamplona, 2004, p. 225.

84. APNP, notario Juan de Salaberria, Pamplona, 1717, 21-I.

85. ADP C/938-n ${ }^{\circ} 1$.

86. ADP, C/713-n'33. 
Cruzat, así como todos los vestidos de don Carlos de Cruzat en sus cofres, una toalla de oro bordada, dos sábanas de Roan y dos de Holanda, la ropa blanca ordinaria, dos tapicerías - una de red blanca y la otra de raso vieja-, un cintillo de oro y cinco picas de oro de "cinturar"87. Por su parte, en el inventario post mortem de la palaciana de Irurozqui, doña Mariana Pérez de Jáuregui, fechado en 1643 se recogía junto a un largo elenco de posesiones rurales, la mención de diferentes sábanas y mantas, manteles viejos y nuevos y únicamente como vestimentas, cinco sayas y dos camisas de paño negro "andadas" así como una capa o herreruelo de Contray, "andado" también ${ }^{88}$.

En 1523, obtenido el perdón del emperador, el señor de Sarría recobró diferentes bienes de los que había sido desposeído por sus inclinaciones políticas y su inicial oposición al monarca castellano. Entre todos ellos resultan curiosas las cuentas de ricas telas, hechuras y vestidos obtenidos por dicho noble, don Francés, en 1545 y 1546. Se invirtieron 1.800 reales en el vestuario de su hija Greida y del esposo de ésta y otros 800 en el suyo propio. Con destino a la joven doncella fueron anotados, por ejemplo, un terciopelo de grana para verdugados, un paño para sayas, tafetán negro para mantos, un paño veintidoseno de Valencia de raso grana, etc. ${ }^{89}$. Don Pedro de Adansa, beneficiado, junto con Pedro de Alzórriz, apotecario, y otros consortes vecinos también de Lumbier se reunieron en 1647 como testamentarios y administradores de los bienes de Catalina de Alzórriz. En aquella reunión se hizo un registro de las posesiones y objetos que habían pertenecido a esta dama navarra, recogiéndose en él la presencia de diferentes ropas de cama, maderas de cabecera de cama con cielo de terciopelo azul, siete colchones de lana y dos de risca y varias arcas con ropa interior, vestidos y jubones que no se describen ${ }^{90}$. Casi medio siglo después, en 1690, el abad de Oricin había muerto ab intestato quedando como heredero su sobrino don Luis de Donamaría, dueño del palacio del lugar, en cuya casa había

87. AGN, TT.RR., Procesos judiciales, 15011, fol. 62v-63v. En el inventario de los bienes de la marquesa de Falces Ana María de Peralta se encontraban piezas procedentes también de Holanda y alguna de Rouen (Francia) así como toallas de Cambrai, de gran aceptación y fama entre las damas. AGN, TT.RR., Procesos judiciales, 151409. No obstante, los materiales más utilizados en la confección textil destinada a la nobleza navarra eran el raso, la seda, el tafetán, el terciopelo, las telas adamascadas, el cuero en el calzado, y las cintas de colores, hilos de oro o plata y ribetes para guarnecerlas. Los gorros solían ser de fieltro y las gorras de uso doméstico de raso. Las prendas eran compradas por los grandes titulados navarros a importantes mercaderes de renombre de Madrid o Valladolid, mientras que la nobleza media titulada se abastecía normalmente en Pamplona. En numerosas ocasiones se abrían pleitos entre nobles y comerciantes por la exigencia de estos últimos en el cobro de prendas impagadas por los caballeros y damas navarras. Ver: Archivo General de Simancas [AGS], Contaduría de Mercedes, leg. 1024, $\mathrm{n}^{\circ} 24$.

88. AGN, TT.RR., Procesos judiciales, 149996, fols. 6v-7v.

89. IDOATE IRAGUI, F., El Señorío de Sarría. Pamplona, 1959, p. 232.

90. ADP, C/970-n ${ }^{\circ}$. 
vivido el difunto hasta su muerte. Entre las pertenencias del abad, Juan de Armendáriz, se mencionan una chaquetilla, un calzón de "paño muy ordinario", un jubón blanco de lienzo con mangas de tafetán nuevas, tres toallas, veinte paños de lienzo, dos paños de manos de terliz en un arca, que según el palaciano "son de una mujer del lugar de Unzué y los tenía en imperio o prenda de dos robos de trigo su tío"

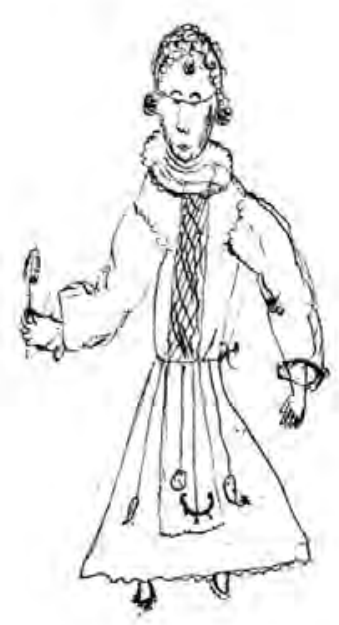

Figura 4: Dama navarra del Antiguo Régimen².

Si un sector de la población de la Península Ibérica se distinguió del resto debido a uno de sus ropajes, fue el de las mujeres de la franja costera cantábrica y del Pirineo occidental: cántabras, vizcaínas, alavesas, guipuzcoanas y navarras. Todas ellas poseían un modo particular de vestir, siendo la parte más Ilamativa de su atuendo sus extraordinarios tocados. Los viajeros del siglo XVI que visitaron aquellas regiones, los describían comparándolos con el cuello y la cabeza de un gallo, con los cestos de cerezas o con gigantescas colmenas. Estas tocas variaban de una región a otra e incluso de un valle a otro. En el siglo XVII se seguían utilizando en algunos valles del Pirineo aragonés y en Navarra

91. ADP, C/963-n 24 , fols. 17-19v.

92. Fuente: AGN, TT.RR., Procesos judiciales, 74485. 
así como en las montañas de Cantabria y Asturias. En un inventario de los retratos del guardajoyas real tras la muerte de Felipe II se describía un cuadro con una dama representada llevando una de estas tocas, lo cual confirma su uso por las damas nobles originarias de estos lugares: "con una ropa amarilla bureteada, forrada de martas, con un tocado de unas tocas a lo vizcaíno"93.

En el lienzo que Mazo, yerno de Velázquez, pintó en 1647 con ocasión de la visita del monarca a Pamplona se observan varias mujeres con tocas propias de Navarra y a diferentes hombres luciendo sombreros de ala ancha $^{94}$. Los cuellos de los trajes de los protagonistas del lienzo son de lino y no de encaje, como sí son los de los danzantes que bailan con magníficos pañuelos en un lateral del cuadro ${ }^{95}$. Durante el siglo XVII en el Valle de Roncal las mujeres cubrían sus cabezas con una toca renacentista, semejante a la ansotana. Estas montañesas sólo a mitad del siglo XVIII tras duros enfrentamientos con la Junta del Valle lograron cambiar dicha toca (Ilamada 'taika' en el dialecto vasco roncalés) por mantillas más cómodas, aunque con colores que determinaban la situación y el estatus social de cada fémina ${ }^{96}$. Ya en 1600, de mano del recién nombrado visitador del obispado de Pamplona Felipe de Obregón, se promulgó una orden que condenaba el uso de este tipo de tocados so pena de excomunión: "se manda a las mujeres que traen tocados con aquellas figuras altas a modo de lo que todo el mundo entiende, hábito indecente, de mujeres honradas, como ellas lo son y de que entren en la iglesia con él por ser figura indecente y escandalosa [fálica]". Tal aviso quedó por ejemplo estampado en el libro parroquial de Lesaca. A pesar de ello, éstos siguieron siendo usados en la montaña navarra. El visitador de Pamplona se vio entonces obligado a lanzar otra en 1623 dirigida a los pueblos de la Ulzama: "mandamos a las mujeres que traen el tocado que llaman

93. Archivo del Palacio Real [APR], Inventario Real de los bienes que se hallaron en el guardajoyas del rey don Felipe II que santa gloria haya (1598), II, fol. 922. En otro inventario de bienes de un monarca español, en concreto el de los cuadros que Felipe IV poseía en el Alcázar de Madrid en 1636 se apunta que en la Escalera de la Reina colgaban "dos lienzos al óleo que son los trajes del Valle de Roncal, el uno con cinco figuras en que hay un hombre, y el otro de siete figuras de mujeres, la última viuda tapada la cara". Citado por MARTíNEZ LEIVA, G. y RODRÍGUEZ REBOLLO, A., Qvuadros y otras cosas que tienen su Majestad Felipe IV en este Alcázar de Madrid. Año de 1636. Madrid, 2007, p. 71.

94. Estos sombreros son parecidos al tradicional de Roncal que ya fue registrado en la talla de la sillería barroca del siglo XVIII, ubicada en el coro de la iglesia parroquial de Isaba donde aparecen, entre otras escenas de la vida rural roncalesa, los representantes de este valle realizando el ceremonial del Tributo de las Tres Vacas con sus vecinos de Baretous.

95. ARIZMENDI AMIEL, Ma . E., Vascos y trajes. San Sebastián, 1976, tomo I, p. 186.

96. ORDUNA PORTÚS, P., "Estudio etnológico del hogar en el Valle de Roncal". Cuadernos de Etnología y Etnografía de Navarra, 79 (2004), pp. 211-278; Idoate Iragui, F., Rincones de la Historia de Navarra. Pamplona, 1954, vol. 1, pp. 389-396. 
'tontorra' [pináculo] se lo quiten y pongan el que se usa de nuevo por la mucha fealdad que causa"97.

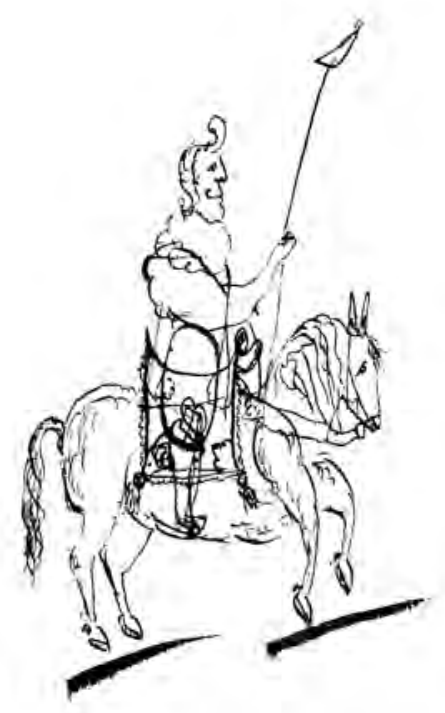

Figura 5: Caballero navarro del Antiguo Régimen ${ }^{98}$.

Se observa cómo la moda simplificó la sofisticación Renacentista a lo largo del siglo XVII. Aunque en las primeras décadas del Seiscientos algunos elementos perduraron en el vestuario de la nobleza -las mangas o las 'cuchilladas'-, el vestido se mostraba mucho más sobrio que el estilo alemán imperante años antes ${ }^{99}$. El negro se había hecho el color más habitual en los jubones, herreruelos e

97. Citado por URANZU, L., Diccionario del Bidasoa. Irún, 1959, pp. 417-418.

98. Fuente: AGN, TT.RR., Procesos judiciales, 74485.

99. Las mangas, prenda desconocida en el norte de Europa, según Laver, en la península eran de uso corriente. LAVER, J., Breve historia del traje y la moda, Madrid, 1988, p. 76. Estas prendas en Navarra aparecen mencionadas en el guardarropa de los marqueses de Falces de 1643. AGN, TT.RR., Procesos judiciales, 151409. Los herreruelos por su parte eran unas capas cuyo uso se popularizó bajo el reinado de Felipe II, quien las incorporó enseguida a su vestuario personal. Las 'cuchilladas' eran unas rasgaduras en la tela que dejaban ver el forro de la misma 
incluso en algunos vestidos de las damas de la aristocracia. Una nueva filosofía y concepción de la vida, propia del Antiguo Régimen español, se había adueñado de los patrones de los sastres y modistos. Un ejemplo de ello lo tenemos entre los vestidos que la vizcondesa de Castejón dejaba a elegir en herencia a su hija María Antonia de Beaumont y Navarra Mesia ya que más de uno eran de ese $\operatorname{color}^{100}$. La ropa durante el Antiguo Régimen fue considerada un bien transmisible al afianzar su papel como símbolo y manifestación del rango social, en gran medida debido a su valor económico. Posesiones trasmitidas bien de una generación a otra o como objeto de donaciones privadas -incluso entre señores y criados- llegando a ser en ocasiones parte de las cantidades estipuladas como dotes o arras. De esta manera, la vizcondesa de Castejón, además del vestido que daba a escoger a su hija, en su testamento reservaba para dos parientes suyas, Leonor y Polonia de Peralta "un manto de soplillo que tengo, pidiéndole que me perdone demostración tan corta, y reciba sólo el afecto [...] Dejo a mi señora doña Polonia de Peralta, un manto de Sevilla nuevo que tengo, explicándola lo mismo que a mi señora doña Leonor"101.

Como podemos apreciar, el Renacimiento había acabado con la universalidad propia del traje medieval evitando que hasta el siglo XVIII volviera a aparecer una moda común en todo Occidente. En el siglo XVII en Europa las diferencias en el vestir eran muy marcadas entre los diferentes territorios. Se podía hablar de diferentes modas -a la manera española, francesa, italiana, etc.-. Sin embargo, pese a esta rica disparidad de tipos, existieron centros de sastrería que influyeron en mayor o menor medida más allá de sus limites fronterizos. Ya bien adentrados en el siglo XVII le tomó el relevo la moda francesa a la par que su Corona suplantaba a la española como primera potencia política y militar. Los tejidos se volvieron más finos, vaporosos y coloridos. A pesar de que todavía se llevaban los colores oscuros, nuevos tonos de azules, amarillos, verdes o rosas, así como dibujos a rayas o cuadrados, comenzaron a ganar terreno. Los colores, hechuras y tejidos podían expresar significados muy concretos no necesariamente regulados por la ley ${ }^{102}$. En cualquier caso, al igual que el negro era de rigurosa etiqueta cortesana en Madrid, en el Valle de Roncal los ribetes rojos en los trajes señalaban la vecindad, y por ende hidalguía universal del portador, y el color amarillo en cambio la carencia de este estatus social y la pertenencia a

sacándose éste a través de ellas. Propias del traje masculino, sobre todo en el siglo XVI, con el tiempo se acabaron extendiendo al atuendo femenino.

100. AGS, Contaduría de Mercedes, leg. 1.181, nº 10.

101. AGS, Contaduría de Mercedes, leg. 1.181, nº 10.

102. SARTI, R., Vida en familia. Casa, comida y vestido en la Europa Moderna. Barcelona, 2003, pp. 258-264. 
un grupo marginado sin derecho a vecindad y participación pública en la comunidad -como podía ser el caso de los agotes-.

En cualquier caso, se puede afirmar que desde la Antigüedad romana hasta la época de la Revolución Francesa de 1789 no habían existido diferencias sustanciales, desde el punto de vista ornamental, en los atavíos de hombres y mujeres. En la historia del vestido el final del siglo XVIII, según Squicciarino, constituyó un fenómeno de notable importancia cuyas consecuencias aún se perciben hoy en día ${ }^{103}$. A finales del Setecientos el sexo masculino renunció a toda forma de atavío espectacular, lujosa y elaborada reduciendo la indumentaria a un estilo más austero y sobrio. Sin embargo, desde ese momento la mujer sería quién gozaría del 'privilegio' de disfrutar del lujo y la elegancia de la alta costura. Para Flügel, esta renuncia al ornato en la vestimenta de los hombres se puede atribuir a factores sociales y políticos estrechamente unidos a los fenómenos revolucionarios que dieron paso al Nuevo Régimen en Occidente ${ }^{104}$. La indumentaria dejó de enfatizar las diferencias de rango y riqueza que la aristocracia hasta ese momento había expresado entre otras maneras a través de lo suntuario en el vestir y la joyería.

\section{Conclusiones: algo más que simple cultura material}

Resulta sumamente difícil la reconstrucción total y fiel de la vida cotidiana de un grupo social histórico. A pesar de ello, a través de los datos analizados en este artículo, podemos intuir de qué forma la condición social privilegiada que disfrutaba la nobleza se manifestaba en su cultura material. Al estudiar el origen y la evolución de sus lugares habitacionales, hemos podido percibir que paulatinamente fue abandonando los entornos rurales de los que provenían gran parte de sus damas y caballeros y se fue afincando en el mundo urbano. Esto conllevó la edificación de nuevas residencias palaciegas, que aspiraban no sólo a conseguir mayor confort de vida sino también a manifestar el poder real y la influencia plena de estos nobles en su entorno comunitario. No obstante, ya desde el Medioevo aquellos que disfrutaban y podían hacer pública su hidalguía, la manifestaban a través de una complicada simbología reflejada en el diseño de nuevas fachadas, escudos, tumbas y otros espacios públicos. Si nos centramos en el examen de necesidades elementales como la vestimenta, podemos observar cómo la nobleza navarra supo adaptarse a las innovaciones de su tiempo y amoldar su poder adquisitivo tanto a sus necesidades primarias como a las honoríficas. Esta última exigencia era propia de un estamento privilegiado que poseía un alto nivel de vida y que supo hacer de actos tan cotidianos como el vestir un alarde de su propia filosofía existencial y de su papel predominante como elite social incluso en épocas de carestía y crisis general.

103. SQUICCIARINO, N., El vestido habla: consideraciones psico-sociológicas sobre la indumentaria. Madrid, 1998, pp. 81-82.

104. FLÜGEL, J. C., Psicología dell'abbigliamento. Milán, 1982, pp. 123-126. 